\title{
WestVirginiaUniversity
}

THE RESEARCH REPOSITORY @ WVU

Graduate Theses, Dissertations, and Problem Reports

2002

\section{Comparison of buffered grazing systems for beef cattle}

Charles R. Wolfe III

West Virginia University

Follow this and additional works at: https://researchrepository.wvu.edu/etd

\section{Recommended Citation}

Wolfe, Charles R. III, "Comparison of buffered grazing systems for beef cattle" (2002). Graduate Theses, Dissertations, and Problem Reports. 1511.

https://researchrepository.wvu.edu/etd/1511

This Thesis is protected by copyright and/or related rights. It has been brought to you by the The Research Repository @ WVU with permission from the rights-holder(s). You are free to use this Thesis in any way that is permitted by the copyright and related rights legislation that applies to your use. For other uses you must obtain permission from the rights-holder(s) directly, unless additional rights are indicated by a Creative Commons license in the record and/ or on the work itself. This Thesis has been accepted for inclusion in WVU Graduate Theses, Dissertations, and Problem Reports collection by an authorized administrator of The Research Repository @ WVU. For more information, please contact researchrepository@mail.wvu.edu. 


\title{
Comparison of Buffered Grazing Systems for Beef Cattle
}

\author{
Charles R. Wolfe III, B.S. Animal Bioscience
}

\author{
Thesis submitted to the \\ Davis College of Agriculture, Forestry, and Consumer Sciences \\ West Virginia University \\ In partial fulfillment of the requirements \\ For the degree of \\ Master of Science \\ In \\ Animal and Veterinary Sciences
}

\author{
Edward C. Prigge, Chair \\ ${ }^{1}$ William B. Bryan \\ Paul E. Lewis \\ Division of Animal and Veterinary Sciences \\ ${ }^{1}$ Division of Plant and Soil Sciences
}

Morgantown, West Virginia

2002

Keywords: Pasture, Cows, Calves, Sward Height, Botanical Composition, Herbage Mass, Forage, Rotational, Continuous

Copyright 2002 Charles R. Wolfe III 


\title{
ABSTRACT \\ Comparison of Buffered Grazing Systems for Beef Cattle
}

\author{
Charles R. Wolfe III
}

To evaluate the productivity of a rotational versus continuous grazing system for beef production within a buffer grazing system, thirty crossbred beef cows and their calves were grouped by weight and randomly assigned to one of the two grazing systems replicated twice over three years at the initiation of each grazing season. Each replication of the rotational system was stocked with 8 cow/calf pairs $(2.45$ cow/calf units/ha pasture and buffer) while the continuous system was stocked with 7 cow/calf pairs $(2.1 \mathrm{cow} / \mathrm{calf}$ units/ha pasture and buffer). The grazing season was divided into 3 periods to aid in analysis. Period 1 (spring grazing) included the time between grazing initiation until buffer grazing began, period 2 ran from the beginning of buffer grazing until the middle to the end of August, and period three ran from the middle to the end of August until weaning. The period 1 and before buffers were grazed was divided into grazing cycles consisting of 4 weeks each. Pasture height was not different $(\mathrm{P}>0.10)$ between systems when averaged over year, however there were differences due to year $(\mathrm{P}<0.059)$. Pasture height also decreased $(\mathrm{P}<0.001)$ over the periods of the grazing season. There was a year $\mathrm{x}$ period interaction $(\mathrm{P}<0.009)$ concerning pasture growth. Growth rate during 1995 was $14 \mathrm{~kg} \mathrm{DM} / \mathrm{ha} / \mathrm{d}$ during period 1 than the growth rate for period 1 during 1996. Growth rate during periods 2 and 3 of 1996 exceeded the rate in 1995 by $3 \mathrm{~kg} \mathrm{DM} / \mathrm{ha} / \mathrm{d}$ and $14 \mathrm{~kg}$ $\mathrm{DM} / \mathrm{ha} / \mathrm{d}$ respectively for the same period. Pasture growth during cycle I (weeks 1-4) was found to be higher $(\mathrm{P}<0.080)$ on the continuous as opposed to the rotational grazed buffer system. No differences $(\mathrm{P}>0.10)$ were found between system or years when green 
herbage mass was considered. Total herbage mass was not different between systems although differences were observed $(\mathrm{P}<0.094)$ between years. Year influenced the proportion of legumes $(\mathrm{P}<0.001)$, weeds $(\mathrm{P}<0.075)$, and dead material $(\mathrm{P}<0.035)$ during weekly cycle I of the grazing season. Change in individual cow weight was not different $(\mathrm{P}>0.10)$, however, cow weights did differ $(\mathrm{P}<0.021)$ between years at weaning. Although there was no difference between systems regarding individual calf gain $(\mathrm{P}>0.10)$, there was a difference $(\mathrm{P}<0.001)$ between systems when total gain per treatment was considered with higher gains on the rotational system. The difference seen in total weight gain was due to the extra calf carried on the rotational system.

Keywords: pasture, cows, calves, sward height, pasture growth, botanical composition, herbage mass, forage quality 


\section{ACKNOWLEDGEMENTS}

I would like to express my thanks to the Department of Animal and Veterinary Sciences, West Virginia University, for the wonderful opportunity given to me and the support for my research endeavors. I would like to thank Dr. Edward C. Prigge for serving as the chairman of my committee and for serving as my advisor during my stay at West Virginia University. I would like to express my deepest thanks to Dr. William B. Bryan for all of his help with my analysis and for serving on my graduate committee. I would also like to than Dr. Paul E. Lewis for his support, encouragement, and for serving as one of my committee members. I thank Dr. Thayne and George Seidel for their help with statistical analysis.

I would like to express my appreciation to Eric Nestor and John Bombardiere for their help with fieldwork and lab analysis. Thanks to Tammy Miller Webster for her help and assistance with lab procedures. I would like to express my warmest thanks and appreciation for all of the help, encouragement, and support given to me by my fellow graduate students Ondieki (James) Gekara and Marcella Schettini. I would like to thank all of my fellow graduate students and work studies that helped me along the way as well.

I would like to thank my family for their support and encouragement through all

of my endeavors. Last but not least, I would like to thank my Christy for her love, encouragement, understanding, and support in everything I do. 


\section{TABLE OF CONTENTS}

Page

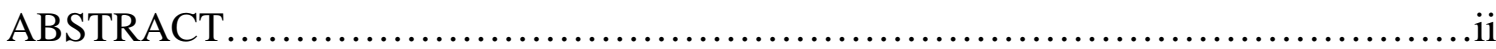

ACKNOWLEDGEMENTS.......................................................



LIST OF FIGURES..................................................................

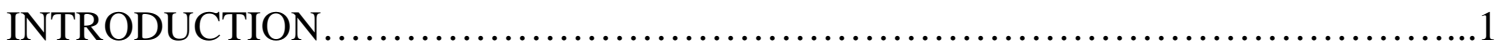

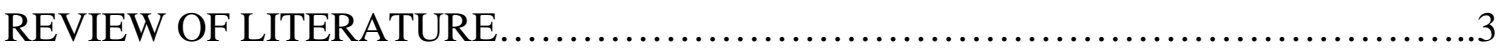

Grassland Utilization Problems.........................................................

Cool Season Growth Curve and Stocking Rate.......................................

Rotational Grazing Systems.....................................................

I. Types of Rotational Grazing Systems

II. Rotational Grazing Experimentation

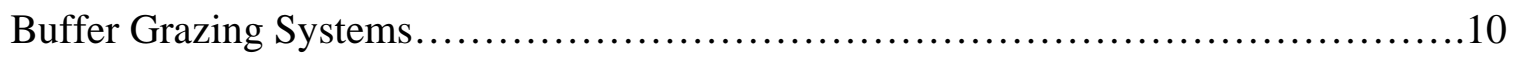

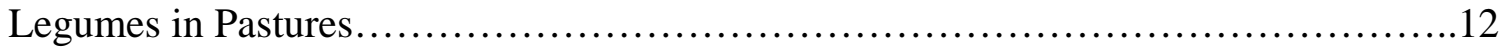

I. Nitrogen Fixation

II. Nitrogen Transfer

III. Problems Associated with Legume Grazing

Nitrogen Fertilization..........................................................

I. Nitrogen Fertilization Experimentation

II. Economics of Nitrogen Fertilization

MATERIALS AND METHODS

Experimental Design

Animal and Grazing Management 


\section{Sward Management}

Sward Sampling Procedures

Forage Analysis

Statistical Analysis



Climatic Report...........................................................25

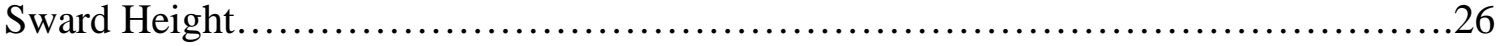

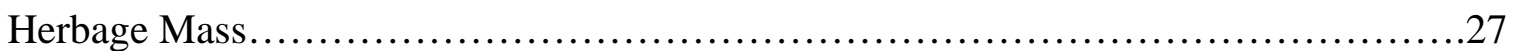

Pasture Growth Rate...........................................................28

Botanical Composition.......................................................29

Forage Quality........................................................... 30

Animal Performance............................................................

SUMMARY AND CONCLUSION ............................................. 34

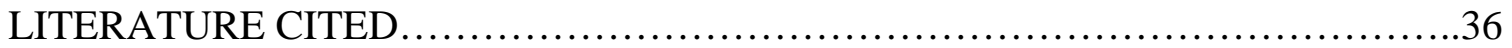

TABLES.......................................................................

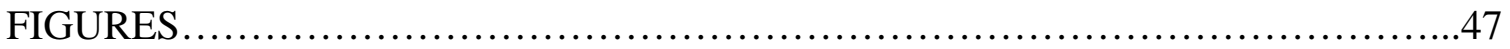

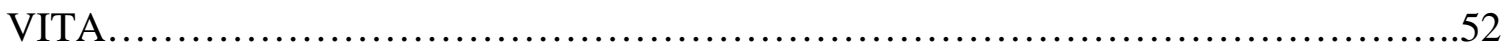




\section{LIST OF TABLES}

$\begin{array}{ll}\text { Table } & \text { Page }\end{array}$

1 Climate Data (1994-1996) and Departures from Normal from Reedsville Experiment Station...................................................40

2 Effect of System, Year, and Period on Sward Height........................41

3 Effect of System, Year, and Period on Herbage Growth Rate.....................41

4 Effect of System and Year on Available Herbage Mass and Botanical Composition, Weeks 1-4 (1994-1996)...................................42

5 Effect of Week on Botanical Composition, 1995 Entire Season.................43

6 Effect of System, Year, and Cycle on Forage Quality, (1994-1996).............44

7 Effect of System and Year on Cow Performance............................45

8 Effect of System and Year on Calf Performance..............................46 


\section{LIST OF FIGURES}

$\begin{array}{lll}\text { Figure } & \text { Page }\end{array}$

1994 Weekly Pasture Heights...............................................47

21995 Weekly Pasture Heights...................................................48

31996 Weekly Pasture Heights................................................49

41995 Pasture Growth and Precipitation........................................50

$5 \quad 1996$ Pasture Growth and Precipitation.....................................51 


\section{INTRODUCTION}

Maximum productivity of grazing systems in terms of gain per hectare is usually attained when the sward is managed to achieve its optimum growth rate. However, risk of low individual animal performance associated with irregular annual forage production accounts for the low stocking rates used in many grazing enterprises (Illius and Lowman, 1984). Grazing buffers can be a safeguard allowing producers to stock pastures heavily in the attempt to achieve maximum productivity. In buffer grazing systems a portion of the grazing area is set aside, which can be harvested for first cutting hay before incorporation into the grazing area. In a buffer grazing system, grazing-only areas are normally stocked at a high rate early in the season. After removal of first cutting hay from a separate area (buffer), and after sufficient regrowth occurs, this buffer area is then added to the grazing-only area. The reduction in stocking density that occurs when the buffer is opened to grazing helps alleviate problems associated with the decrease in pasture production normally seen in the Northeastern United States during the summer months (Holmes, 1980).

Rotational grazing is a grazing management that utilizes two or more paddocks grazed in succession. For each paddock a rest period is included, during which no grazing occurs, which allows the pasture to accumulate regrowth while the animals are grazing another paddock in the rotation. Studies comparing rotational grazing to continuous stocking managements have shown inconclusive results in most cases, although reports of 30-50\% improvements in production per ha have been reported (Holmes, 1980). McMeekan and Walshe in 1963 reported that rotational grazing pastures 
had a 5-10\% higher optimum stocking rate compared to continuous stocked pastures. Rotational grazing may be more advantageous at higher stocking rates due to greater forage productivity.

Maximum efficiency and productivity of grazing systems is highly dependant on stocking rate. Therefore the need to investigate the interaction between buffer and rotational grazing systems at high stocking intensity exits; given that both rotational and buffer grazing systems have been shown experimentally to increase stocking rates. Consequently, the objective of this study was to determine if incorporation of rotational grazing into a buffer grazing system would increase productivity. 


\section{Review of Literature}

\section{Grassland Utilization Problems}

Pasture grazing is an important element in most profitable beef production systems. Grazing provides an economically viable feed source, eliminating the need for additional investments for harvesting and conserving feeds. Seasonality of pasture growth is an inescapable occurrence that must be dealt with by livestock producers who depend on grazing. Uneven distribution of pasture production can be attributed to a single or several interacting factors, which include temperature, light, moisture, fertility, or pests (Blaser et al., 1973). Distribution of grassland production and changing demands for nutrients by animals may not coincide. Normally, as the season advances, energy demands increases in both cow/calf and stocker production systems, while pasture production decreases (Blaser et al., 1973). Animal needs throughout the year can be manipulated to some extent by modifying breeding schedules or by adjusting stocking rates. Another approach is to change feed allocation by grazing management such as rotational and buffer grazing systems.

\section{Cool Season Growth Curve and Stocking Rate}

The rate of growth of all grass species varies enormously during the year. When cool season grasses are considered in the Northeastern United States, measurable pasture growth can be seen in March and the rate of growth accelerates through April reaching a 
peak some time during May. After peak growth is reached, growth rate declines until August when a second, much smaller, peak can sometimes be observed. Growth rate declines as the season progresses, reaching non-measurable levels in November (Holmes, 1980).

The traditional management on many beef grazing systems is set stocking of pasture throughout the grazing season. Set stocking for the entire growing season presents management problems, if the pasture is stocked heavily to utilize the abundant spring growth, pasture growth will not be sufficient during the mid-summer months to meet animal requirements.

A high stocking rate will allow for higher animal output per hectare but often lower individual animal production. Heavy spring stocking rates limit the accumulation of largely unpalatable, senescent plant material, which can make the pasture less productive. If pastures are stocked at a low rate to compensate for the low producing summer months, there will be a large accumulation of undergrazed, senescent patches, which produce no additional dry matter and shade out growth of both clover and additional grass. This accumulation of mature forages lowers production and quality of pastures (Blaser et al., 1969). Experimental results from Illius et al. (1986) indicate that, by controlling the intensity of defoliation in early season to maintain a short sward with a high proportion of green material, it is possible to obtain high production in late-season at high stocking rates. Low early-season stocking rates can lead to a dilution of late season sward with senescent material resulting in poor animal performance (Illius et al., 1986). Undergrazing may also lead to an increase in the proportion of unpalatable, weedy species in the pasture, again lowering the productivity of the grassland. 
Maximum quality of pasture is attained when swards are kept closely grazed and plants are in their young, productive stage. The difficulty in achieving maximum quality and yield is that the need to graze closely can lead to overgrazing, suppressing pasture growth and animal intake.

\section{Rotational Grazing Systems}

Rotational grazing is a grazing management that utilizes two or more pastures which are grazed successively. A rest period, during which no grazing occurs, allows the pasture to accumulate regrowth while the animals are grazing another paddock in the rotation. The grazing period is the number of days within each cycle that each paddock is grazed while the rest period refers to the number of days in the cycle when the paddock is unoccupied. The rotation or grazing cycle is defined as the total number of days elapsing from the beginning of one grazing period in a paddock until the beginning of the next period in that same paddock (Holmes, 1980). Many variations of rotational grazing management are possible. Some forms of rotational grazing include rigid rotational grazing, flexible rotational grazing, paddock grazing, strip grazing or a combination of methods used at different times during the grazing season.

\section{Types of Rotational Grazing Systems}

Rigid rotational grazing is a management where animals spend the same amount of time grazing each paddock in the rotation according to a predetermined schedule. An example of a commonly used system is the Wye College System, which includes 4 
paddocks, each grazed for one week with three weeks of rest (Holmes, 1980). Rigid rotational grazing is easy to manage and does not require a great deal of management skill because animals are moved according to a timetable, not according to available herbage.

The rotation schedule of a flexible rotational grazing system varies according to the quantity of available herbage present. Grazing and rest periods are variable and are constantly changing. The flexible rotational grazing systems requires more management skill than the rigid system, the manager must determine when to move the animals according to available herbage.

Paddock grazing refers to either a rigid or flexible rotational grazing system consisting of a large number of paddocks, normally occupied for one day each. Strip grazing can be used within a rotational grazing system or in a single field. A new strip of herbage is made available on a daily basis to the grazing animals by moving a temporary electric fence (Holmes, 1980).

\section{Rotational Grazing Experimentation \\ Rotational grazing has been practiced for nearly 400 years (Wheeler, 1962).}

Experiments comparing rotational and continuous stocking (constant occupation of the entire pasture area) have been inconclusive. Improvements of $30-50 \%$ in production per ha with rotational grazing, compared to continuous stocking, have been reported (Holmes, 1980). Continuous stocking has also been shown experimentally to be superior to rotational grazing, particularly in studies done with sheep (Wheeler, 1962). 
Rotational grazing systems are believed by many to have the capacity to carry higher stocking rates than continuous stocking. In an experiment published by McMeekan and Walshe in 1963, the optimum stocking rate under rotational grazing was found to be 5-10\% higher than under continuous stocking with lactating dairy cattle. At high stocking rates they found an $8 \%$ advantage in milk production per cow per acre with rotational grazing. At low stocking rates, rotational and continuous grazing showed no difference in milk production. Bertelsen et al. (1993) conducted a grazing study over a period of two years to compare continuous stocking, and rotational grazing, utilizing both six and eleven-paddock systems. Along with test heifers that were weighed in the study, put-and-take heifers were used to maintain forage heights in the 8 to $15 \mathrm{~cm}$ range and to vary treatment stocking rates. Although average daily gains were not affected by the grazing systems, gains per ha for the six and eleven paddock systems were $40 \%$ and $34 \%$ greater compared to continuous stocking, respectively. It has been stated that rotational grazing can support higher stocking rates without a decrease or with only a small reduction in per animal production, however, results can vary greatly depending on climate, soil, topography, weather, type of forage, and type of animal utilized in the experiment (Holmes, 1980).

When stocking rates are equal, rotational grazing increased animal production per acre by up to 9\% in an experiment carried out by Hodgson et al. in 1934 and increased production by $13 \%$ in an experiment by McMeekan in 1957 compared to continuous stocking. Schlepers and Latinga (1985), with nitrogen fertilization levels of $400 \mathrm{~kg}$ $\mathrm{N} / \mathrm{ha} / \mathrm{yr}$, showed insignificant differences between rotational grazing and continuous stocking with dairy cattle. These findings are supported by other reports using high 
nitrogen levels (Ernst et al., 1986, and Parsons et al., 1983). The majority of experiments in which the same stocking rate was used showed little difference between rotational and continuous grazing (Wheeler, 1962). Rotational grazing is more advantageous when stocking rates are higher most likely due to greater forage productivity. In experiments comparing continuous and rotational grazing at variable stocking rates, the more heavily stocked grazing system was almost always more productive (Wheeler, 1962). Results of many grazing experiments comparing rotational and continuous grazing must be viewed with caution since, in practice, all of the cases in which stocking rates were used, the rotational system was stocked more heavily (Wheeler, 1962).

There are several possible explanations for the many differences in results of studies comparing rotational and continuous grazing. One possibility is that at low stocking rates, continuous grazing systems normally allow more grazing selectivity. The diet eaten by grazing animals normally contains higher proportions of leaf and live plant material and lower proportions of stem and dead material than that found in the sward as a whole (Hodgson, 1990). The plant material normally selected by the animal, when given the opportunity, are more nutritious than the average of the entire sward. In the experiment carried out by Bertelsen et al. (1993), grazing pressure was maintained at a high level by the use of put-and-take heifers. Because the grazing pressure was kept high, there was less opportunity for selective grazing. The diet consumed by continuously grazing heifers was found to be higher in NDF than that of heifers grazing rotationally. Continuously stocked pastures were found to have available forage higher in NDF, ADF, and ADL; CP content of available herbage was found to be lower in continuous stocked pastures than in the rotational paddocks before grazing began. After grazing, forage 
quality was not different from the forage available in the continuously stocked pasture. The quality disparity seen before and after grazing in the rotational paddocks was a result of grazing selectivity by the cattle. Available forage in the paddocks was drastically reduced as a result of grazing. Rotationally grazed paddocks produced more forage and provided higher quality herbage in this study compared to continuously grazed pastures.

Rotational grazing has been a recent topic of research in regard to controlling parasites. Most endoparasites require a minimum of three days between the time when the egg or early larvae stage are voided until they reach an infective stage. Because the infective stage is only a few weeks under certain climatic conditions, it is theoretically possible to reduce or eliminate parasitic infections by rotational grazing (Wheeler, 1962). However, experimental evidence has shown no difference in parasite infection levels between rotational and continuous grazing systems (Smeal et al., 1969; Goldberg and Lucker, 1969). Climatic conditions such as precipitation, temperature, and humidity can largely affect the survival of parasites distributed on the pasture (Wheeler, 1962).

Rotational grazing is a favored grazing management system for dairying in Maritime climates. In a Maritime climate, pasture growth occurs year round, although with a marked seasonal pattern of growth (McCall et al., 1999). The premise of many managers in these areas is that the most profitable grazing option is to allow cattle to harvest the pasture directly. In the absence of conserved forage, lactation is curtailed in autumn to allow for the accumulation of standing forage for grazing during the winter and early spring. Seasonal calving is normally practiced and lactations are 225-250 days in length (McCall and Clark, 1999). Rotational grazing is normally employed in these 
situations to maximize pasture productivity because of the need to manage overgrazing and seasonal pasture production (McCall et al., 1999).

Producers who rely on continuous stocking do so for a variety of reasons: much of the land used for grazing can not be cut for hay or silage, profit margins are too low to support additional fixed costs involved with fencing and labor, and trials comparing rotational and continuous grazing fail to show any justification for the additional input of fencing and labor (Mackie et al., 1986).

\section{Buffer Grazing Systems}

Maximum efficiency in grazing systems is generally attained at high stocking rates. The risk to individual animal performance associated with the unpredictable annual variation in grass growth accounts for the low stocking rates currently used in many pasture programs (Illius and Lowman, 1984). Because many farmers are fearful of stocking their pastures at high rates due to annual inconsistency in pasture growth, the buffer grazing system has received attention in recent years in an attempt to limit the risk of heavily stocked pastures against seasonal variability in pasture production. Different buffers have been examined as supplements for pasture during times of scanty grass growth. Concentrates have been tested as buffers but they have proven to be inefficient because of a depression in herbage intake well beyond termination of concentrate feeding (Illius et al., 1986). Concentrate feed acts as a substitute, rather than a supplement to pasture and grazing animals do not utilize available herbage to its fullest. An additional feed source can be evaluated for its effectiveness as a true supplement by monitoring 
grass height. If grass height increases rapidly, the feed source is being used as a substitute for grazing (Mackie et al., 1986). Silage feeding as a buffer to pasture has shown similar responses as buffer grazing but the additional capital investment required to make and store silage makes silage feeding less advantageous (Mackie et al., 1986).

In buffer grazing systems a portion of the grazing area (called a buffer) is set aside, which can then be harvested as first cutting hay or silage. This buffer area is excluded from grazing early in the grazing season when grass growth is rapid. The Edenburgh Buffer Grazing System (Illius and Lowman, 1984) recommends setting aside a portion of the pasture area between $25-33 \%$ as a buffer. First cutting hay or silage is normally removed from the buffer area and regrowth is allowed to accumulate before grazing during the summer months. Grazing the buffer area during times of inadequate forage growth reduces grazing pressure on the pasture. In the buffer grazing system additional herbage is allotted as the season progresses to compensate for increased animal requirements. It is recommended (Allen and Spedding, 1984) that buffer grazing begin as soon as pasture height falls below five $\mathrm{cm}$. Because the buffer is used as an insurance policy, it may not be used in years with ample grass growth and consequently can be harvested for more conserved forage. Another advantage of the buffer grazing system is that it allows for a more efficient utilization of the sward.

Many producers traditionally stock their pastures at a low rate during the spring in anticipation of poor herbage production during the dry, summer months. Low stocking rates in spring reduce animal production because sub-optimal utilization of the herbage results in accumulation of senescent forage. It is less well recognized that sward conditions resulting from early season management have a lasting influence on gains of 
cattle during the second half of the grazing season (Illius et al., 1986). The need to stock heavily in spring reaffirms the usefulness of a buffer grazing system.

Grazing research by McMeekan and Walshe (1963) in New Zealand has highlighted the importance of stocking rate as a dominant management factor determining the efficiency of pasture utilization, with grazing method playing a substantially less important role. If stocking rates are to be increased and hence grazing efficiency is to be improved, grazing buffers are necessary to provide an insurance policy to individual animal performance (Lowman and Illius, 1986).

\section{Legumes in Pastures}

Legumes, when incorporated into cool-season pastures, have been shown to increase pasture production although they are included in relatively few acres (Cuomo et al., 1999). Legumes have the ability to fix atmospheric dinitrogen $\left(\mathrm{N}_{2}\right)$ via a symbiotic relationship with nitrogen fixing bacteria (rhizobia). Legumes can improved the productivity of grass-legume stands by adding a high quality component to the total herbage as well as by increasing the quality and quantity of the grass component by transferring fixed nitrogen from legume roots to the grass.

\section{Nitrogen Fixation}

Rhizobia are a motile, non-spore forming, rod-shaped bacteria of the genus Rhizobium, family Rhizobiaceae (Allen, 1973). The legume plant and rhizobia share a mutually beneficial relationship. The plant partner, or macrosymbiont, provides the 
environment where the bacterial partner, or microsymbiont, receives nutrition from the plant for growth and reproductive purposes. The plant provides photosynthetic products and other nutrients to the bacteria, which is located within a root structure called a nodule. Bacteria not only use the plant-derived energy for the synthesis and maintenance of their cells, but also to supply energy for the highly energetically taxing process of dinitrogen reduction from the atmosphere (Heichel, 1985). Although the process of $\mathrm{N}$ reduction is energetically costly, the total amount of energy used by a grass-legume mixture is more efficient than a system based on grass and nitrogen fertilization (Person and Ison, 1997). Rhizobia convert gaseous $\mathrm{N}_{2}$ to ammonium ions, a valuable nutrient to plants, which the plant then converts to amino acids for protein synthesis. Given the proper conditions, symbiosis can provide nitrogen in excess of the host plant's requirements, although, the average rhizobia fix approximately $75 \%$ of its requirement (Heichel, 1985). It is estimated that rhizobia fix approximately $90 \times 10^{6}$ metric tons of nitrogen annually worldwide (Tisdale et al., 1993).

The amount of $\mathrm{N}_{2}$ fixed by the legume is dependent on several factors. The particular legume must be infected by the proper bacterial strain to obtain functional nodules. Legume seeds are normally coated with the appropriate inoculant, which assures adequate infection of the root system. If a particular legume has been present in a grassland and has been properly inoculated, an inoculant may not be necessary (Heichel, 1985). The number of rhizobia in the soil is greatly reduced by antagonistic conditions such as drought, lack of essential mineral elements such as: calcium, potassium, and phosphorous, and $\mathrm{pH}$ levels above 8 or below 5 (Allen, 1973). 
The amount of $\mathrm{N}_{2}$ fixed by legumes also varies by legume species. A pure stand of red clover typically fixes $129 \mathrm{~kg} \mathrm{~N} / \mathrm{ha} / \mathrm{yr}$, with a reported range of $85-189 \mathrm{~kg} \mathrm{~N} / \mathrm{ha} / \mathrm{yr}$. Other typical $\mathrm{N}$ fixation values for pure stands are: white clover $112 \mathrm{~kg} \mathrm{~N} / \mathrm{ha} / \mathrm{yr}$, alfalfa $224 \mathrm{~kg} \mathrm{~N} / \mathrm{ha} / \mathrm{yr}$, and trefoil $118 \mathrm{~kg} \mathrm{~N} / \mathrm{ha} / \mathrm{yr}$ (Tisdale et al., 1993). The N status of the soil greatly affects the proportion of $\mathrm{N}$ contained in the legume that is derived from fixation (Heichel, 1985). The proportion of legume-N originating from bacteria can range from 30 to $60 \%$ in highly fertile soils and nearly $100 \%$ in infertile soils (Person and Ison, 1997).

\section{Nitrogen Transfer}

Nitrogen is fixed by bacteria and stored in root nodules, it is available for transfer to associated grass species after death and decay of nodules and roots (Dubach and Russelle, 1994) or by being discharged from legume roots (Ta et al., 1986). It appears that the primary means of transfer is root and nodule turnover (Laidlaw et al., 1996).

The amount of $\mathrm{N}$ transferred from legumes to grasses in a particular stand varies. This has been examined to try to determine the exact contribution that $\mathrm{N}$ transfer has on the uptake of $\mathrm{N}$ by grass in grass-legume mixtures. Mallarino et al. (1990) seeded tall fescue stands with various legumes and estimated the transfer of $\mathrm{N}$ to the tall fescue by using ${ }^{15} \mathrm{~N}$ isotope dilution to be $18 \mathrm{~kg} / \mathrm{ha}$ for the first year and $34 \mathrm{~kg} / \mathrm{ha}$ for the second

year of establishment. Farnham and George (1994) studied a mixture of birdsfoot trefoil and orchard grass. The fixation of $\mathrm{N}$ range was from 90 to $138 \mathrm{~kg} \mathrm{~N} / \mathrm{ha} / \mathrm{yr}$. The orchard grass obtained $8 \%$ of its total nitrogen by transfer from birdsfoot trefoil in the first year and $42 \%$ in the second year. The amount of $\mathrm{N}$ transferred is influenced by a variety of 
factors such as total amount of $\mathrm{N}$ fixed, $\mathrm{N}$ status of the soil, and growing conditions (Person and Ison, 1997).

\section{Problems Associated with Legume Grazing}

Legumes are seeded in relatively few acres of pasture for several reasons although they may occur voluntarily. Pastures with a significant proportion of legumes are normally harder to manage than a pure grass stand. If not properly managed legumes can be grazed out of a pasture in a relatively short period of time. One study with pasture renovation, was carried out by Cuomo et al. (1999) to establish the optimum herbage residual height and to determine the most persistent legumes in a grazing situation. Pastures were rotationally grazed by lactating dairy cows. Established cool-season pastures consisting primarily of orchard grass and tall fescue were overseeded with various legumes (alfalfa, red clover, white clover, birdsfoot trefoil). A control with no legume was also included in the study. Plots were grazed to three different residual heights: low $(5-10 \mathrm{~cm})$, medium $(10-15 \mathrm{~cm})$, and high $(15-20 \mathrm{~cm})$. It was found that the low grazed plots produced less forage mass per year than those grazed higher. Residual heights between 10 and $20 \mathrm{~cm}$ were recommended to optimize forage production as well as to maintain overseeded legumes. Renovated pastures averaged $46 \%$ more forage mass than the control pastures over the three years of the study and alfalfa and red clover were found to be the most persistent overseeded legume. Finally, it was determined that the additional forage produced by pasture renovation cost between $\$ 8.07$ and $\$ 12.81 /$ ton. A conflicting view is given about optimum residual height when grazing grasslegume mixtures (Blaser et al., 1973). Short stubble is recommended for optimizing 
legume persistence in pastures. The lower leaf area index (LAI) of short grazed grass is hypothesized to depress regrowth of the grass and allow the legume to better compete for light with the taller growing grass. Rotational grazing has been recommended for legume grazing because of the better opportunity for residual height control and prevention of overgrazing (Taylor, 1973).

Another reason for the reluctance of managers to incorporate legumes into their grazing systems is the risk of bloat. While legume grazing does increase the risk of bloat, grass-legume mixtures reduce this tendency.

Although legume incorporation into pastures requires a higher level of management, benefits can outweigh costs. Legumes not only increase the quality of the available forage, but they also fix valuable nitrogen, which can be beneficial to grass growth (Cuomo et al., 1999).

\section{Nitrogen Fertilization}

In the majority of cases, soil is an inadequate source of $\mathrm{N}$. Nitrogen is extremely critical to forage quantity and quality. In spite of this, the amount of fertilizer $\mathrm{N}$ currently used is well below that considered economically optimal (Doyle and Wilkins, 1984).

Nitrogen is required for photosynthesis, growth, and reproduction in plants. The green photosynthetic pigment, chlorophyll, is partially composed of $\mathrm{N}$ (Woodhouse and Griffith, 1973), however, the majority of $\mathrm{N}$ absorbed by plants is incorporated into plant protein. 


\section{Nitrogen Fertilization Experimentation}

A multitude of experiments indicate a large increase in herbage yield and stocking rates as a result of $\mathrm{N}$ fertilization (Holmes, 1980). Differences in sites as to the response to applied $\mathrm{N}$ do exist. There are several reasons for these differences, the major one being $\mathrm{N}$ status of the soil. Soils deficient in $\mathrm{N}$ ordinarily show more dramatic responses to applied $\mathrm{N}$. The presence of legumes in a pasture normally reduces the response to $\mathrm{N}$ fertilization.

Recovery of applied $\mathrm{N}$ is also quite variable and is normally between 50 and $80 \%$, although recoveries can exceed $100 \%$ because the application makes soil $\mathrm{N}$ more available (Rhykerd and Noller, 1973). The increase in $\mathrm{N}$ harvested in forage is almost invariably less than the amount of fertilizer $\mathrm{N}$ applied. Some $\mathrm{N}$ is retained in roots and unharvested stubble and will eventually be recovered. Nitrogen leached from the soil and removed in runoff is lost from the system. Another type of loss is denitrification that results in gaseous loss of $\mathrm{N}$ from the soil.

The appropriate amount of $\mathrm{N}$ to apply annually is a debatable issue. Rhykerd and Noller (1973) claim that the highest percent recovery in forage grasses in the United States is seen at rates of $200-300 \mathrm{~kg} \mathrm{~N} / \mathrm{ha} / \mathrm{yr}$; lower rates result in $\mathrm{N}$ retention in roots and stubble, while at higher rates $\mathrm{N}$ may not be totally absorbed. Research has demonstrated large responses in animal output per hectare to increases in fertilizer $\mathrm{N}$ up to $450 \mathrm{~kg} / \mathrm{ha}$ per year (Meat and Livestock Commission, 1983). These findings are further supported by records indicating a linear relationship between stocking rate and $\mathrm{N}$ usage up to 350 $\mathrm{kg}$ N/ha per year (Milk Marketing Board, 1982). In Ireland N fertilization at $360 \mathrm{~kg} / \mathrm{ha}$ 
increased stocking rates by an average of $80 \%$ compared to $60 \mathrm{~kg} \mathrm{~N} / \mathrm{ha}$ in an experiment by Steen and Laidlaw (1986).

Another factor influencing the effectiveness of $\mathrm{N}$ application is timing. The most convenient and least costly method of application is a single application at the start of or

during a period of rapid growth. Application during this time of rapid growth will ensure high utilization. The problem with this single application during rapid growth is that the increase in production comes at a time when excess forage is already available for grazing (Pearson and Ison, 1997). It is traditional in Great Britain to apply $\mathrm{N}$ in several even dressings over the entire growing season. This split application method results in a more even distribution of growth throughout the growing season (Doyle and Wilkins, 1984). Morrison et al. (1980) found that herbage yield distribution can be altered by strategic $\mathrm{N}$ applications throughout the season, with the most even growth occurring with heavier applications in mid-season.

\section{Economics of Nitrogen Fertilization}

The most economic $\mathrm{N}$ application rate varies by farm, field location, labor availability, ability of manager, climate, and value of products sold just to name a few. Utilization of the increased forage production, resulting from applied $\mathrm{N}$ is paramount in justifying any level of $\mathrm{N}$ application economically (Minderhoud et al., 1974). 


\section{Materials and Methods}

\section{Experimental Design}

A cow-calf production system experiment comparing two grazing managements: continuous stocking and rotational grazing, was conducted at the West Virginia University farm at Reedsville, WV during the 1994, 1995, and 1996 grazing seasons. Systems were compared by measuring animal weight change, forage production, and quality. A randomized complete block design with two treatments and two replications was used. The experimental area (14 ha) consisted of two 7 ha blocks. Block I was situated on the north facing slopes and block II was situated on the south facing slopes. Each block contained one 3.5 ha replication of the two treatments. Each replication consisted of 2 ha pasture, used exclusively for grazing and 1.5 ha buffer, used to make first cutting hay and then used for grazing. The soils were in the Warton (fine-loamy, mixed, mesic, Aquic Hapludults), Dekalb (loamy-skeletal, mixed, mesic, Typic Dystroschrepts), Ernest (fine-loamy, mixed, mesic, Typic Fragiudults), and Gilpin (fineloamy, mixed, mesic, Typic Hapludults) series.

For both management systems, fifty-seven percent of the area was grazed in the spring ( 2 ha) and $43 \%$ was utilized as a buffer (1.5 ha) to be opened to grazing after removal of first cutting hay and sufficient regrowth occurred. The buffer area was opened to grazing prior to hay removal or appropriate regrowth if sward height dropped below $3.5 \mathrm{~cm}$ on the 2 ha area used exclusively for grazing.

In the continuously stocked system, the area where grazing only occurred was set stocked until the buffer was available. Once sufficient regrowth occurred after hay 
removal from the buffer area, that area was open to grazing only along with the grazing area and continuously stocked.

In the rotational system, the spring grazed area was divided into four equal subplots (0.5 ha each) and grazed rotationally. For the first eight weeks, each subplot was grazed for a period of 7 days or to a height of $3.5 \mathrm{~cm}$, before cattle were rotated to the next plot in the rotation. After the first eight weeks the subplots of the rotational system were either grazed individually or in combination until buffers were ready for grazing as determined by the amount of regrowth. The early grazing season was divided into two 4-week cycles for comparison. Each cycle consisted of one complete rotation through the four subplots of the rotational buffer system. After regrowth of the buffer, it was included in the grazing area and continuous stocking commenced. There were yearly differences in the management of the pasture area after the two four week cycles for the rotational system and before the buffer was included in the grazing area as dictated by yearly difference in forage regrowth.

\section{Animal and Grazing Management}

Thirty multiparous crossbred beef cows calving between February 1 and April 1 and their calves were assigned according to calving date, gender, and weight into four groups. They were randomly assigned to one replicate of each grazing system. The continuous system was stocked with 7 cow/calf units $(2.1$ cow/calf units/ha of pasture and buffer), while the rotational system was stocked with 8 cow/calf units $(2.45 \mathrm{cow} / \mathrm{calf}$ units/ha of pasture and buffer) because of anticipated higher pasture production with the rotational system. Pastures were stocked at a high rate to assure that animal production would be sensitive to forage productivity. 
Spring grazing began once sward height reached approximately $6 \mathrm{~cm}$, which was May 5 in 1994, May 2 in 1995, and May 8 in 1996. Calves were weaned on October 3 in 1994, October 2 in 1995, and September 27 in 1996. Animal performance data were collected up until the time of weaning. Cows were stocked continuously on the grazing areas (pasture plus buffer) after weaning until forage became limiting $(<3.5 \mathrm{~cm}$ sward height). It was planned to feed hay when sward heights dropped below $3.5 \mathrm{~cm}$ during the grazing season but this was unnecessary. Cows were given access to trace-mineralized salt $^{1}$ (Morton International, Inc. Chicago IL) on a free choice basis. Cows and calves were weighed at the initiation of grazing, at weaning, and approximately at monthly intervals each year.

\section{Sward Management}

Species composition in the pasture areas was primarily Kentucky bluegrass (Poa pratensis $\mathrm{L}$ ) and white clover (Trifolium repens $\mathrm{L}$ ). In the hay and buffer areas, orchardgrass (Dactylis glomerata L), and tall fescue (Festuca arundinacea Schreb) were the predominant forage species present as determined by visual observation.

Hay fields and buffers were fertilized with $55.6 \mathrm{~kg} \mathrm{~N} / \mathrm{ha}$ in early April. Soil samples were taken in the fall of each year. Soil $\mathrm{pH}$ was maintained at 6.1 and available $\mathrm{P}$ and $\mathrm{K}$ averaged $111 \mathrm{~kg}$ and $237 \mathrm{~kg} / \mathrm{ha}$ respectively on all plots in the study.

\section{Sward Sampling Procedures}

Pasture growth rate and botanical composition were determined using grazing exclusion cages measuring $1.2 \times 1.2 \mathrm{~m}$. Growth rate $(\mathrm{kg} / \mathrm{ha} / \mathrm{d})$ was estimated from the difference between sward height measurements when exclusion cages were put in place and at the end of the grazing cycle (normally 4 weeks later). Exclusion cages were used

\footnotetext{
${ }^{1} 95-98 \% \mathrm{NaCl}, 0.35 \% \mathrm{Zn}, 0.28 \% \mathrm{Mn}, 0.175 \% \mathrm{Fe}, 0.035 \% \mathrm{Cu}$, and $0.007 \% \mathrm{Co}$
} 
only in 1995 and 1996 where 8 cages were used per system for each block ( 2 cages per plot in the rotational system). At each placement 4 sward heights were measured within the cage using an acrylic plastic plate (Rayburn and Rayburn, 1998). In 1994, 5 sward heights were taken within each subplot in the rotational system on a weekly basis and 20 samples were collected at the beginning of a grazing cycle in the continuous system. Sward heights were averaged per paddock. Sward growth rate was the difference between sward height at the end and beginning of a growth period divided by the length of the period using the following formula:

$\underline{\text { Sward height at end }(\mathrm{cm})-\text { Sward height at beginning }(\mathrm{cm})}$

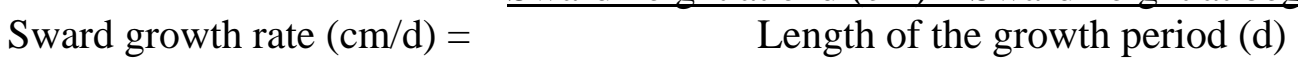

Sward growth rate $(\mathrm{cm} / \mathrm{d})$ was then converted to herbage accumulation rate $(\mathrm{kg} / \mathrm{ha} / \mathrm{d})$ by means of a regression equation according to the procedure of Bryan et al. (1990) and developed from data collected at this location.

Herbage accumulation rate $(\mathrm{kg} / \mathrm{ha} / \mathrm{d})=$ Sward growth rate $(\mathrm{cm} / \mathrm{d}) * 201.7+6.2, \mathrm{R}^{2}=0.80$

Herbage accumulation was analyzed by periods. Period I ran from the initiation of grazing until buffer grazing began (July 19). Period II ran from the initiation of buffer grazing until August 24 in 1995 and until August 16 in 1996. Period III was from the end of period II until weaning. 
Botanical composition of rotationally grazed pastures was determined from clip samples cut weekly on the subplot being grazed at the present time within two exclusion cages and at two other randomly selected areas outside the exclusion cages.

Continuously stocked pastures were sampled at the beginning of the 4-week grazing cycle in the same manner as the rotationally grazed subplots. Forage samples were collected by battery powered grass shears, clipping a $0.45 \times 0.45$ area at ground level, and the samples were frozen $\left(-20^{\circ} \mathrm{C}\right)$ until thawing $\left(22^{\circ} \mathrm{C}\right)$ for separation into components (grass, weeds, legumes, dead material) for botanical composition determination. Individual components were then dried in an oven $\left(80^{\circ} \mathrm{C}\right)$ to constant weight and dry matter determined, as described by AOAC (1990). These data were taken during the first two 4-week cycles each year.

Available green herbage mass (GHM) and total herbage mass (THM) were analyzed by way of clip samples taken from a $0.45 \times 0.45 \mathrm{~m}$ area taken from within the grazing exclusion cages. Clip samples dried and weighed and sorted with the dead material within the sample being excluded from the GHM determination. An equation was used relating the mass of the sample clipped to the total herbage on the entire plot.

Sward height was monitored by taking approximately 50 readings/plot using a plate meter as described by Rayburn and Rayburn (1998). Measurements were not taken under trees, in rocky areas, on bare ground, or near fences.

Weather data were collected at the Reedsville farm. Daily precipitation and minimum and maximum temperatures were recorded over the three years of the experiment. Thirty-year averages of temperature and precipitation were recorded and are reported for comparison. 


\section{Forage Analysis}

Forage samples obtained from inside and outside of exclusion cages were combined and ground in a Wiley mill (Thomas Scientific, Swedensboro, NJ) to pass through a $1 \mathrm{~mm}$ screen. Samples were then combined over block, system, weekly cycle, and year. Dry matter (DM) and crude protein $(\mathrm{CP})$ were analyzed according to the procedure described by AOAC (1990). Neutral detergent fiber (NDF) was analyzed according to procedures described by Van Soest et al. (1991). Acid detergent fiber (ADF) was determined by procedures described by Robertson and Van Soest (1981).

\section{Statistical Analysis}

The data were analyzed as a split plot arrangement of treatments in a randomized complete block design using the GLM procedure of SAS (1985) to observe differences in treatments. The main plots consisted of either rotational or continuous grazing systems and the subplots consisted of either high or low fertility assignments. Analysis of variance (ANOVA) was performed using an $\mathrm{F}$ test $(\mathrm{P}<0.10)$ to determine the effect of grazing system on animal performance and herbage production. 


\section{Results and Discussion}

In all three years of the study, 7 cow/calf pairs $(2.1$ cow/calf units/ha of pasture and buffer) were stocked on each replication of the continuous buffered system and 8 pairs were stocked on each replication of the rotational buffered system $(2.45$ cow/calf units/ha of pasture and buffer). The difference in stocking rates between systems was based on estimated differences in forage production. For both systems the stocking rate was considerably greater than the rate for the average beef production enterprise in the Appalachian region, which is less than 1 cow/calf unit/ha. Intense stocking was utilized in this study to ensure that animal performance would be sensitive to forage production. Grazing began on May 6 in 1994, May 3 in 1995, and May 8 during 1996. Hay was harvested on buffer and hay areas on June 24 during 1994, June 14 during 1995, and on June 19 during 1996. Buffer grazing began on July 14 during 1994, July 19 during 1995, and July 10 during 1996. Data collection was terminated when calves were weaned on October 3 in 1994, October 2 in 1995, and on September 27 in 1996.

\section{Climatic Report}

Averages and departures from average are presented in Table 1 for both temperature and precipitation. Total precipitation for the three years of the study were: $163 \mathrm{~cm}$ during 1994, $132 \mathrm{~cm}$ during 1995, and $201 \mathrm{~cm}$ during 1996. During the grazing season of 1994 (April - October), ambient temperatures were below normal for the months of May, August, September, and October. Precipitation was below the 30-year average in June, July, September, and October although there was only $1.6 \mathrm{~cm}$ less precipitation during the 1994 grazing season than the average of the previous 30 years. 
In 1995, ambient temperatures were below normal in April, May, and September during the growing season. Precipitation was below normal during the months of April, June, July, and September. The total precipitation for the 1995 -grazing season was $5 \mathrm{~cm}$ below the 30-year average.

In the 1996 grazing season temperatures were below normal during April, May, July, August, September, and October while precipitation was below normal during only June and October. Total precipitation during the grazing season was $40 \mathrm{~cm}$ above the 30 year average.

\section{Sward Height}

Seasonal changes in sward height of grazing areas are illustrated in figures 3, 4, and 5 for 1994, 1995, and 1996, respectively, for the entire grazing season. Pasture height fell below $3.5 \mathrm{~cm}$ only once during the study which was in 1995 , for the rotational system during week 12, before the buffer was incorporation into the grazing area. The buffer area was not grazed at this point since regrowth was not sufficient. Buffers in all three years were not utilized for grazing until regrowth occurred, 3-4 weeks after removal of first cutting hay. No supplemental hay was utilized in any of the grazing systems at any time.

No grazing system $\mathrm{x}$ year or system $\mathrm{x}$ period interactions were found in sward height $(\mathrm{P}>0.10)$. System did not influence $(\mathrm{P}>0.10)$ sward height (Table 2). Sward height differed between years (Table $2, \mathrm{P}<0.059$ ) most likely because of climate variability or the result of carry over effects of the heavy stocking rate utilized in previous years. Average pasture height was $0.3 \mathrm{~cm}$ less in 1995 compared to 1994 and nearly $0.9 \mathrm{~cm}$ less for 1996 compared to 1995 . Precipitation during the growing season 
for 1994 and 1995 was less than normal, 1.6 and $5.0 \mathrm{~cm}$ less than average, respectively. Although 1996 received nearly $40 \mathrm{~cm}$ more precipitation than normal, some months received considerably more rainfall than others. Runoff may have been significant during periods of heavy rain, making rainfall data less useful in explaining sward heights and pasture growth rates (Table 1). Periods (Table 2) during the grazing season were also found to differ $(\mathrm{P}<0.001)$ in sward height. Sward height decreased from period 1 (grazing initiation until mid July) to period 2 (Mid July until mid to late August) by nearly $2.5 \mathrm{~cm}$. Sward heights were similar in both periods 2 and 3 differing by less than $1 \mathrm{~cm}$. The warmer, dryer climate during the summer months (Table 1), could reduce pasture growth rate (Table 3). Also another possible contributing factors to the lower herbage height in period 2 and 3 is the increasing energy requirements of the grazing cattle as calves mature.

\section{Herbage Mass}

Available green herbage mass (GHM) and total herbage mass (THM) were evaluated for the first 4 weeks of the 1994 and 1996 grazing seasons (Table 4). Herbage mass was not evaluated for the 1995 season because of lost data. No interactions $(\mathrm{P}>0.10)$ were found between years and systems regarding GHM and THM.

No difference $(\mathrm{P}>0.10)$ was found between years regarding GHM, although THM was different $(\mathrm{P}<0.094)$ between years of the study. Total herbage mass was $1000 \mathrm{~kg}$ DM/ha greater in 1994 as compared to 1996. In 1994, there was no difference ( $>0.10)$ between systems regarding GHM or THM. There was a difference $(\mathrm{P}<0.076)$ between systems regarding GHM in 1996 . The continuous system had nearly $350 \mathrm{~kg}$ more GHM 
dry matter per ha than the rotational system. Total herbage mass was also $550 \mathrm{~kg}$ higher $(\mathrm{P}<0.008)$ on the continuous system compared to the rotational system in 1996.

The portion of the season following the first 4 weeks of grazing was analyzed for 1995 (Table 5). No difference ( $>$ >0.10) was seen between systems regarding GHM and THM presence.

\section{Pasture Growth Rate}

Pasture growth rate was analyzed for the 1995 and 1996 growing seasons comparing system, year, and period (Table 3). No interactions $(\mathrm{P}>0.10)$ were found between years and grazing systems in pasture growth. Growth on the continuous system was higher $(\mathrm{P}<0.080)$ than the rotational system. A possible reason for this is that the continuous system had forage removed on a regular basis unlike the rotational system, which normally had a 3-week rest period. Grazing forages on a regular basis may have encouraged tillering, which could possibly increase growth rates (Penning et al, 1991). In addition each replication of the continuous system was stocked with 7 cow/calf units while the rotational system was stocked with 8 units. The heavier stocking rate on the rotational system may have resulted in the removal of more photosynthetic material, thus lowering forage growth rates.

There was an interaction $(\mathrm{P}<0.009)$ between years and period of the grazing season. Pasture growth during period 1 (spring grazing) in 1995 exceeded that for period 1 in 1996 by $14 \mathrm{~kg} \mathrm{DM} / \mathrm{ha} / \mathrm{d}$. Growth rate was slightly higher in 1996 during the $2^{\text {nd }}$ period (pasture and buffer grazing until mid to late August) of the grazing season than that in 1995. Growth rate during period 3 (mid to late August until weaning) of 1996 was more than twice the rate of 1995 for this period. Growth during the latter portion of the 
growing season normally exceeds the growth seen during the mid summer months in the northeastern United States (Holmes, 1980). This was not the case in 1995 where growth during the $3^{\text {rd }}$ period of the grazing season was less than the growth rate during period 2. One possible reason for the low growth rate during period 3 of 1995 could be the amount of precipitation occurring during that time as can be seen in the climate report (Table 1). Precipitation was higher for all periods in 1996 than 1995 although the difference was most pronounced during period 3 where there was an average of $0.10 \mathrm{~cm} /$ day precipitation in 1995 compared to $0.22 \mathrm{~cm} /$ day in 1996 .

Considering both systems, pasture growth varied according to period $(\mathrm{P}<0.05)$ with period 1 averaging $49.1 \mathrm{~kg} \mathrm{DM} / \mathrm{ha} / \mathrm{d}$, period 2, $15.7 \mathrm{~kg} \mathrm{DM} / \mathrm{ha} / \mathrm{d}$, and period 3, 19.9 $\mathrm{kg} \mathrm{DM} / \mathrm{ha} / \mathrm{d}$. This is a normal seasonal pattern of growth for cool season pastures in the Northeast (Holmes, 1980) and it is related to temperature and rainfall distribution over the growing season. (Figure 6, Figure 7).

\section{Botanical Composition}

Botanical composition for the 1994 and 1996 grazing seasons, regarding the proportion of grass, legumes, weeds, and dead material was determined for the first 4 weeks of the grazing season (Table 4). A system $\mathrm{x}$ year interaction was found for both the proportion of grass $(\mathrm{P}<0.071)$ and legumes $(\mathrm{P}<0.013)$ in the sward. In 1994, the rotational system had a greater proportion of grass compared to the continuous system, however in 1996 the continuous system had a greater proportion of grass than the rotational system. A possible reason for this is that the greater intensity of grazing over the long term for the rotational system may be more conducive to the accumulation of other sward components such as legumes and weeds at the expense of grass. In 1994, the 
continuous system had a greater proportion of legumes than the rotational system, while in 1996 where there was a higher proportion of legumes on the rotational system than the continuous system. Again, the more intense, intermittent grazing on the rotational system was perhaps more favorable for the legume proportion of the pasture resulting in an increasing proportion of this component from 1994 to 1996. The differences seen in legume proportion on the rotational system from 1994 to 1996 may be a combination of reduced competition for sunlight because of a higher average sward height in 1994. Average sward height over the entire grazing season in 1994 was $1.2 \mathrm{~cm}$ higher than the average height in 1996.

Proportion of grass and dead material was measured following weeks 1-4 for the remainder of the 1995 grazing season only. No differences $(\mathrm{P}>0.10)$ were found between systems for proportion of grass and dead material although the rotational system had a lower proportion of dead material than the continuous system (Table 5).

\section{Forage Quality}

Forage quality was evaluated over all three years of the study for the first 4 weeks of grazing (Table 6). There were no interactions $(\mathrm{P}>0.10)$ between systems and years and no differences $(\mathrm{P}>0.10)$ between systems or years for NDF, ADF, and CP concentrations.

Forage quality was compared for the first 4-week cycle and the second 4-week cycle of the 1995 grazing season only (Table 6). For 1995 interactions were found $(\mathrm{P}<0.067)$ between systems and weekly cycles for the NDF content. In weeks 1-4, NDF content was similar between systems however during weeks 5-8 the rotational system has 3-percentage units higher NDF content than the continuous system. One possible reason

for the higher percent NDF on the rotational system during weeks 5-8 is that the sward on 
the rotational system was normally allowed uninterrupted growth for 3 weeks between grazing. This could have resulted in more mature forage, normally higher in percentage NDF as well as ADF, on the rotational plots. In 1995 there was a difference $(\mathrm{P}<0.036)$ between systems for percent $\mathrm{ADF}$, which was more than 1 percentage unit higher on the rotational sward (Table 6). Although there was no difference between systems, protein composition in 1995 differed $(\mathrm{P}<0.088)$ between weekly cycles with protein percentage increasing from weeks 1-4 to weeks 5-8. Neutral detergent fiber was over 1 percentage unit higher $(\mathrm{P}<0.088)$ during weeks $5-8$ as compared to samples from weeks $1-4$. The higher light intensity and higher ambient temperatures during the second weekly cycle (Table 1) as opposed to the first weekly cycle resulting in slower sward growth may be the reason for the higher NDF proportion in the forage (Holmes, 1980). Protein percentage increased nearly 1 percentage unit $(\mathrm{P}<0.088)$ from weeks $1-4$ to weeks $5-8$. Crude protein content probably increased because of an increase in the legume component of the pastures possibly due to decreased competition for sunlight as sward height decreased from cycle 1 to cycle 2 (Table 2 ).

\section{Animal Performance}

No system $\mathrm{x}$ year interactions were found $(\mathrm{P}>0.10)$ for average gain per animal or total gain per treatment for the cows or calves over the entire grazing season (Table 7 , Table 8$)$. No difference ( $\mathrm{P}>0.10)$, between systems, both on an average animal and total gain per treatment basis, was found when cow weights were considered for period 1 and at weaning. The similar performance between systems indicates that metabolizable energy consumption of the cows was equivalent even considering the heavier stocking rate of the rotational system. This leads to the assumption that growth rate was higher on 
the rotational pasture. Although no difference was seen between years before buffer grazing began (Period 1$)$, differences $(\mathrm{P}<0.021)$ existed between years in average cow gain for the entire grazing season. Average cow gain in 1994 was almost $20 \mathrm{~kg}$ higher than 1995 and over $35 \mathrm{~kg}$ higher than 1996. Yearly cow weight gain differences can possibly be explained by differences in average sward height and forage availability over the grazing season. Sward height was highest in 1994 and decreased over the next two years of the experiment (Table 2). Total herbage mass during weeks 1-4 was similar for 1995 and 1996 but there was over $1000 \mathrm{~kg} \mathrm{DM} / \mathrm{ha}$ less (Table 4) for 1994, further explaining the difference seen in average cow gain between years.

Before opening buffers to grazing (Period 1), average calf gain was not different $(\mathrm{P}>0.10)$ between systems, however total calf gain per treatment was higher $(\mathrm{P}<0.001)$ on the rotational system, yielding $200 \mathrm{~kg}$ more gain per year than the continuous system (Table 8). At weaning, average calf gain was not different between systems, again because of the extra cow/calf unit total calf gain per treatment was higher $(\mathrm{P}<0.001)$ on the rotational than continuous system. The rotational system produced over $150 \mathrm{~kg} / \mathrm{ha}$ more total calf weight gain than the continuous system. Before buffer inclusion the grazing area, the rotational system averaged $299 \mathrm{~kg}$ calf gain/ha while the continuous system produced $249 \mathrm{~kg} / \mathrm{ha}$ per year over the three years of the experiment. After the buffers were included the grazing area and both systems were grazed continuously, the rotational system produced $304 \mathrm{~kg}$ of calf gain/ha/yr while the continuous system produced $267 \mathrm{~kg} / \mathrm{ha} / \mathrm{yr}$. Since there was no difference between systems in average calf gain, the difference observed between treatments in total gain can be attributed to the extra calf carried on the rotational system. Average calf gain was different $(\mathrm{P}<0.053)$ 
between years during period 1. Average gain in 1995 was 6\% higher than in 1994 and $11 \%$ higher than in 1996. Although average calf gain was different during period 1, average calf gain was not different $(\mathrm{P}>0.10)$ between years at weaning. 


\section{Summary and Conclusion}

System did not influence ( $\mathrm{P}>0.10)$ sward height (Table 2). In 1994, there was no difference $(\mathrm{P}>0.10)$ between systems regarding GHM or THM, although there was a difference $(\mathrm{P}<0.076)$ between systems regarding GHM and THM in 1996. The continuous system in 1996 had nearly $350 \mathrm{~kg}$ more GHM dry matter per ha than the rotational system. Total herbage mass was also $550 \mathrm{~kg}$ higher $(\mathrm{P}<0.008)$ on the continuous system compared to the rotational system in 1996. Pasture growth was found to be higher $(\mathrm{P}<0.081)$ on the continuously grazed system than the rotational system in the analysis of the latter 2 years of the experiment.

A higher proportion $(\mathrm{P}<0.011)$ of legumes was found on the rotational system as compared to the continuous system during the study. Other botanical components did not differ $(\mathrm{P}>0.10)$ between systems.

No differences $(\mathrm{P}>0.10)$ between systems were observed for ADF, NDF, or CP component of the pasture during the first 4 weeks of the study during 1994 through 1996. Although a higher $(\mathrm{P}<0.036)$ ADF content was found in the rotational system as compared to the continuous system during the two weekly cycles of 1995.

No difference $(\mathrm{P}>0.10)$ was seen between systems regarding average cow gain during period 1 (before buffer grazing) and at weaning. During period 1, total calf gain per treatment was higher $(\mathrm{P}<0.001)$ on the rotational system than the continuous system, although mean calf gain was no different $(\mathrm{P}>0.10)$, indicating that the difference seen between systems was due to the extra calf carried on the rotational system. At weaning, mean calf gain was not different between systems. Total calf gain per treatment was 
higher $(\mathrm{P}<0.001)$ on the rotational system than the continuous system; once again indicative that the extra calf carried on the rotational system resulted in increased performance per ha over the continuous system. During period 1, the rotational system produced $17 \%$ more calf gain/ha/yr than the continuous system. However after buffers were included the grazing area and continuous grazing commenced on both systems, the rotational system produced only $14 \%$ more calf gain/ha/yr than the continuous system. Findings in this study suggest that the rotational system was superior to the continuous system because of the increased calf liveweight production as a result of the heavier stocking rate supported by the rotational grazing system. 


\section{$\underline{\text { Literature Cited }}$}

Allen, D.M., and A.W. Spedding. 1984. The use of grass in beef production. In Money from grass. Corrall, A.J. (ed.) British Grassland Society Occasional Symposium. No. 15 . pp. 25-33.

Allen, O.N. 1973. Symbiosis: rhizobia and leguminous plants. In Forages. Heath, M.E., D.S. Metcalf, and R.F. Barnes. (eds.) Iowa State University Press, Ames, IA, pp. 98-104.

Bertelsen, B.S., D.B. Faulkner, D.D. Buskirk, and J.W. Castree. 1993. Beef cattle performance and forage characteristics of continuous, 6-paddock, and 11-paddock grazing systems. J. Anim. Sci. 71:1381-1389.

Blaser, R.E., H.T. Bryant, R.C. Hammes, R.L. Bowman, J.P. Fontenot, and C.E. Polan. 1969. Managing forages for animal production. Virginia Polytech. Inst. Research Bulletin No.45, Middleburg, VA.

Blaser, R.E., D.D. Wolf, and H.T. Bryant. 1973. Systems of grazing management. In Forages. Heath, M.E., D.S. Metcalf, and R.F. Barnes. (eds.) Iowa State University Press, Ames, IA, pp. 581-595.

Cuomo, G.J., D.G. Johnson, F. Farcella, M.V. Rudstrom, G.D. Lemme, and N.P. Martin. 1999. Pasture renovation and grazing management impacts on cool-season grass pastures. J. Prod. Agric. 12:564-569.

Doyle, C.J., and R.J. Wilkins. 1984. Grassland and production: realizing the potential. In Money from Grass. Corrall, A.J. (ed.) British Grassland Society Occasional Symposium. No. 15. pp. 11-24.

Dubach, M. and M.P. Russelle. 1994. Forage legume roots and nodules and their role in N transfer. Agron. J. 86:259-266.

Ernst, P., Y.P. Le Du, and L. Carlier. 1986. Animal and sward production under rotational and continuous grazing management. In The Role of Nitrogen in Intensive Grassland Production. Prins, W.H. and Arnold, G.H. (eds.) pp. 119126.

Farnham, D.E., and J.R. George. 1994. Harvest management effects on productivity, dinitrogen fixation, and nitrogen transfer in birdsfoot trefoil-orchardgrass communities. Crop Sci. 34:1650-1653.

Goldberg, A., and J.T. Lucker. 1969. Relationship of rotational grazing to gastrointestinal nemotode infection in cattle. Am. J. Vet. Res. 30:2137-2144. 
Heichel, G.E. 1985. Symbiosis: Nodule Bacteria and Leguminous Plants. In Forages. Heath, M.E., R.F. Barnes, and D.S. Metcalfe (eds.) Iowa State Univeristy Press, Ames, IA. pp. 64-80.

Hodgson, J. 1990. Grazing management science into practice. Whittemore, C.T., K. Simpson (eds.) Longman, Essex, England. pp. 65-76.

Holmes, W. 1980. Grass: its production and utilization. Blackwell Scientific Publications, Oxford, England.

Illius, A.W., and B.G. Lowman. 1984. Operation of the buffer grazing system. In Money from grass. Corrall, A.J. (ed.) British Grassland Society Occasional Symposium. No. 15. pp. 74-75.

Illius, A.W., B.G. Lowman, and E.A. Hunter. 1986. The use of buffer grazing to maintain sward quality and increase late-season cattle performance. In Grazing. Frame, J. (ed.) British Grassland Society Occasional Symposium. No. 19. pp. 119-123.

Laidlaw, A.S., P. Christie, and H.W. Lee. 1996. Effect of white clover cultivar on apparent transfer of nitrogen from clover to grass and estimation of relative turnover rates of nitrogen in roots. Plant and Soil. 179:243-253.

Lowman, B.G., and A.W. Illius. 1986. Advances in beef grazing systems. In Grazing. Frame, J. (ed.) British Grassland Society Occasional Symposium. No. 19. pp. 175-188.

Mackie, C.K., D.S. Yackiminie, and E.A. Hunter. 1986. Grazing with and without supplementary forages (buffers) for beef cattle. In Grazing. Frame, J. (ed.) British Grassland Society Occasional Symposium. No. 19. pp. 138-142.

Mallarino, A.P., W.F. Wedin, C.H. Perdomo, R.S. Goyenola, and C.P. West. 1990. Nitrogen transfer from white clover, red clover, and birdsfoot trefoil to associated grasses. Agronomy J. 82:790-795.

McCall, D.G, and D.A. Clark. 1999. Optimized dairy grazing systems in the northeast United States and New Zealand II. System analysis. J. Dairy Sci. 82:1808-1816.

McCall, D.G, D.A. Clark, L.J. Stachurski, J.W. Penno, A.M. Bryant, and B.J. Ridler. 1999. Optimized dairy grazing systems in the northeast United States and New Zealand I. Model description. J. Dairy Sci. 82:1795-1807.

McMeekan, C.P., and M.J. Walshe. 1963. The inter-relationship of grazing method and stocking rate in the efficiency of pasture utilization by dairy cattle. J. Agric. Sci. 61:147-163. 
Meat and Livestock Commission. 1983. Beef improvement services data sheet 82/5.

Milk Marketing Board. 1982. An analysis of FMS coasted farms 1981-82. Farm Management Services Information Unit Report 33. Reading, UK.

Minderhoud, J.W., P.F.J. VanBurg, B. Deinum, J.G.P. Diruen, and M.L.t Hart. 1974. Effects of high levels of nitrogen and adequate utilization on grassland productivity and cattle performance with special reference to permanent pastures in the temperate regions. Paper presented at XII International Grassland Congress, Moscow, USSR.

Morrison, J., M.V. Jackson, and P.E. Sparrow. 1980. The response of perennial ryegrass to fertilizer nitrogen in relation to climate and soil. Grassland Research Institute Technical Report No. 27, Hurley, England pp. 36-45.

Parsons, A.J., E.L. Leafe, and P.D. Penning. 1983. Crop physiological limitation to production under continuous and rotational grazing. In Efficient Grassland Farming. Corrall, A.J. (ed.) British Grassland Society Symposium No. 14. pp. $145-147$.

Person, C.J. and R.L. Ison. 1997. Grassland-animal interactions and management. In Agronomy of grassland systems. Cambridge University Press, Cambridge, England. pp. 96-113.

Rayburn, E.B. and S.B. Rayburn. 1998. A standardized plate meter for estimating pasture mass in on-farm research trials. Agron. J. 90:238-241.

Robertson, J. B, and P. J. Van Soest. 1981. The detergent system of analysis and its application to human foods. In: W. P.T. James and O. Theander (ed.). The Analysis of Dietary Fiber. pp. 123-158. Marcell Dekker, New York.

Rhykerd, C.L., and C.H. Noller. 1973. The role of nitrogen in forage production. In Forages. Heath, M.E., D.S. Metcalf, and R.F. Barnes. (eds.) Iowa State University Press, Ames, IA, pp. 416-424.

SAS. 1985. SAS Users' Guide: Statistics. Version 5th ed. SAS Institute, Inc., Cary, NC.

Schlepers, H. and E.A. Lantinga. 1985. Comparison of net pasture yield with continuous and rotational grazing at a high level of nitrogen fertilization. Netherlands J. Agric. Sci. 33:429-432.

Smeal, M.G., E.A. Farleigh, and G.W. Major. 1969. Effect of a rotational grazing system on nemotode infection of sheep. Aust. Vet. J. 45:554-557. 
Steen, R.W.J., and A.S. Laidlaw. 1986. Effect of low and high inputs of fertilizer nitrogen on the stock carrying capacity of grass/white clover swards. In Grazing. Frame, J. (ed.) British Grassland Society Occasional Symposium. No. 19. pp. $39-43$.

Ta, T.C., F.D.H. MacDowall, and M.A. Farris. 1986. Excretion of assimilated N fixed by nodules of alfalfa. Can. J. Bot. 64:2063-2067.

Taylor, N.L. 1973. Red clover and alsike clover. In Forages. Heath, M.E., D.S. Metcalf, and R.F. Barnes. (eds.) Iowa State University Press, Ames, IA, pp. $148-158$.

Tisdale, S.L., W.L. Nelson, J.D. Beaton, and J.L Haulin. 1993. Soil fertility and fertilizers ( $5^{\text {th }}$ edition). MacMillan Pub. Co. New York. pp. 109.

Van Soest, P. J., J. B. Robertson, and B. A. Lewis. 1991. Methods for dietary fiber, neutral detergent fiber and non-starch polysaccharides in relation to animal nutrition. J. Dairy Sci. 74: 3583-3597.

Wheeler, J.L. 1962. Experimentation in grazing management. Herbage Abstracts. 32:17.

Woodhouse Jr., W.W. and W.K. Griffith. 1973. Soil fertility and fertilization of forages. In Forages. Heath, M.E., D.S. Metcalf, and R.F. Barnes. (eds.) Iowa State University Press, Ames, IA, pp. 411-415. 
Table 1: Climate Data (1994-1996) and Departures from Normal ${ }^{1}$ from Reedsville Experiment Station

\begin{tabular}{|c|c|c|c|c|c|}
\hline \multirow[b]{2}{*}{ Month } & \multirow[b]{2}{*}{ Year } & \multicolumn{2}{|c|}{ Temperature $\left({ }^{\circ} \mathrm{C}\right)$} & \multicolumn{2}{|c|}{ Precipitation (cm) } \\
\hline & & Average & Departure & Total & Departure \\
\hline \multirow[t]{3}{*}{ January } & 94 & -6.74 & -3.89 & 25.17 & 10.52 \\
\hline & 95 & -2.35 & 0.50 & 14.88 & 0.23 \\
\hline & 96 & -3.41 & -0.55 & 23.22 & 8.56 \\
\hline \multirow[t]{3}{*}{ February } & 94 & -1.90 & -0.25 & 16.13 & 3.74 \\
\hline & 95 & -3.89 & -2.24 & 9.42 & -2.97 \\
\hline & 96 & -3.07 & -1.43 & 17.63 & 5.24 \\
\hline \multirow[t]{3}{*}{ March } & 94 & 2.03 & -1.57 & 21.54 & 7.12 \\
\hline & 95 & 4.24 & 0.64 & 6.78 & -7.64 \\
\hline & 96 & -0.65 & -4.25 & 17.83 & 3.41 \\
\hline \multirow[t]{3}{*}{ April } & 94 & 10.19 & 0.98 & 12.40 & 1.46 \\
\hline & 95 & 7.58 & -1.62 & 7.04 & -3.90 \\
\hline & 96 & 8.27 & -0.94 & 12.60 & 1.67 \\
\hline \multirow{3}{*}{ May } & 94 & 10.98 & -3.07 & 14.05 & 1.05 \\
\hline & 95 & 13.10 & -0.94 & 15.16 & 2.17 \\
\hline & 96 & 13.41 & -0.63 & 27.13 & 14.13 \\
\hline \multirow[t]{3}{*}{ June } & 94 & 19.93 & 1.34 & 9.78 & -2.29 \\
\hline & 95 & 19.23 & 0.64 & 8.71 & -3.36 \\
\hline & 96 & 19.04 & 0.45 & 9.12 & -2.95 \\
\hline \multirow[t]{3}{*}{ July } & 94 & 20.95 & 0.17 & 12.78 & -0.84 \\
\hline & 95 & 21.48 & 0.69 & 6.30 & -7.31 \\
\hline & 96 & 19.07 & -1.72 & 24.82 & 11.20 \\
\hline \multirow{3}{*}{ August } & 94 & 18.61 & -1.43 & 20.47 & 8.83 \\
\hline & 95 & 22.12 & 2.08 & 14.05 & 2.40 \\
\hline & 96 & 19.21 & -0.83 & 12.93 & 1.28 \\
\hline \multirow[t]{3}{*}{ September } & 94 & 14.60 & -1.83 & 6.86 & -2.30 \\
\hline & 95 & 14.86 & -1.57 & 4.80 & -4.36 \\
\hline & 96 & 15.61 & -0.82 & 18.36 & 9.20 \\
\hline \multirow[t]{3}{*}{ October } & 94 & 9.14 & -1.39 & 3.94 & -4.81 \\
\hline & 95 & 10.63 & 0.09 & 11.58 & 2.84 \\
\hline & 96 & 10.18 & -0.35 & 12.78 & 4.03 \\
\hline \multirow[t]{3}{*}{ November } & 94 & 7.24 & 2.32 & 9.63 & -2.70 \\
\hline & 95 & 1.09 & -3.82 & 18.85 & 6.52 \\
\hline & 96 & 0.82 & -4.09 & 11.15 & -1.17 \\
\hline \multirow[t]{3}{*}{ December } & 94 & 2.15 & 2.12 & 10.13 & -3.49 \\
\hline & 95 & -3.92 & -3.95 & 14.53 & 0.91 \\
\hline & 96 & 2.06 & 2.03 & 13.79 & 0.172 \\
\hline
\end{tabular}

\footnotetext{
${ }^{1}$ Average from $1964-1993$.
} 
Table 2: Effect of System, Year, and Period on Sward Height

\begin{tabular}{|c|c|c|c|}
\hline Item & $\begin{array}{l}\text { Sward Height, } \\
\mathrm{cm}\end{array}$ & SEM & Probability \\
\hline Rotational & 5.66 & & \\
\hline Continuous & 5.87 & 0.1 & $\mathrm{NS}^{\mathrm{a}}$ \\
\hline 1994 & 6.28 & & \\
\hline 1995 & 5.95 & 0.1 & $(0059)$ \\
\hline 1996 & 5.08 & & $(0.059)$ \\
\hline Period $1^{\mathrm{b}}$ & 7.23 & & \\
\hline Period $2^{c}$ & 4.74 & 0.1 & $(0.001)$ \\
\hline Period $3^{d}$ & 3.94 & & \\
\hline
\end{tabular}

Table 3: Effect of System, Year, and Period on Herbage Growth Rate

\begin{tabular}{|c|c|c|c|c|c|c|c|c|}
\hline \multirow[t]{2}{*}{ Item } & Year & 1995 & & & 1996 & & & System \\
\hline & Period & 1 & 2 & 3 & 1 & 2 & 3 & Mean \\
\hline \multicolumn{9}{|c|}{ Herbage Growth, $\left(\mathrm{kg}\right.$ DM/ha/d) ${ }^{\mathrm{a}}$} \\
\hline \multicolumn{2}{|c|}{ Rotational } & 54.4 & 10.2 & 13.4 & 40.2 & 17.4 & 25.0 & 34.36 \\
\hline \multicolumn{2}{|c|}{ Continuous } & 60.9 & 18.8 & 12.0 & 47.1 & 17.7 & 28.3 & 39.83 \\
\hline
\end{tabular}

\footnotetext{
${ }^{a}$ Year $\mathrm{X}$ period interaction significant at $\mathrm{P}<0.05$; Difference between systems was significant $(\mathrm{P}<0.081)$, standard error of the mean $=1.0$; Difference between years was non-significant $(\mathrm{P}>0.10)$, standard error of the mean $=1.0$; Difference between periods was significant $(\mathrm{P}<0.001)$, standard error of the mean $=0.8$
} 
Table 4: Effect of System and Year on Available Herbage Mass and Botanical Composition, Weeks 1-4 (1994-1996)

\begin{tabular}{|c|c|c|c|c|c|c|}
\hline Item & $\begin{array}{l}\text { GHM, } \\
\mathrm{kgDM} / \mathrm{ha}\end{array}$ & $\begin{array}{l}\text { THM, } \\
\mathrm{kgDM} / \mathrm{ha}\end{array}$ & $\begin{array}{l}\text { Grass, } \\
\%\end{array}$ & $\begin{array}{l}\text { Legume, } \\
\%\end{array}$ & $\begin{array}{l}\text { Weeds, } \\
\%\end{array}$ & $\underset{\%}{\text { Dead, }}{ }^{\mathrm{d}}$ \\
\hline \multicolumn{7}{|l|}{1994} \\
\hline Rotational & 1772.2 & 2817.0 & 59.5 & 1.9 & 5.0 & 33.6 \\
\hline Continuous & 1704.2 & 3065.2 & 54.3 & 3.8 & 2.5 & 39.4 \\
\hline SEM & 168.9 & 228.7 & 2.2 & 0.6 & 1.4 & 3.8 \\
\hline Probability & $N S^{f}$ & NS & NS & NS & NS & NS \\
\hline \multicolumn{7}{|l|}{1996} \\
\hline Rotational & 1468.9 & 1689.8 & 61.2 & 9.7 & 13.4 & 15.7 \\
\hline Continuous & 1800.9 & 2244.5 & 63.9 & 8.0 & 9.4 & 18.7 \\
\hline SEM & 134.6 & 159.7 & 2.1 & 1.1 & 1.6 & 1.6 \\
\hline Probability & $(0.076)$ & $(0.008)$ & NS & NS & NS & NS \\
\hline 1994 Mean & 1803.6 & 3007.5 & 57.1 & 2.8 & 4.3 & 35.8 \\
\hline 1996 Mean & 1634.9 & 1967.2 & 62.6 & 8.9 & 11.4 & 17.2 \\
\hline SEM & 90.9 & 123.1 & 1.8 & 0.6 & 1.0 & 1.6 \\
\hline Probability & NS & $(0.094)$ & NS & $(0.001)$ & $(0.075)$ & $(0.035)$ \\
\hline Rotational Mean & 1624.0 & 2179.0 & 56.4 & 8.7 & 13.3 & 21.6 \\
\hline Continuous Mean & 1752.5 & 2654.9 & 59.1 & 5.9 & 6.0 & 29.0 \\
\hline SEM & 91.4 & 200.7 & 2.5 & 1.5 & 1.9 & 3.5 \\
\hline Probability & NS & NS & NS & $(0.011)$ & NS & NS \\
\hline
\end{tabular}


Table 5: Effect of Week on Botanical Composition, 1995 Entire Season

\begin{tabular}{lllll}
\hline \hline Item & $\begin{array}{l}\text { GHM, } \\
\mathrm{kgDM} / \mathrm{ha}\end{array}$ & $\begin{array}{l}\mathrm{THM}, \\
\mathrm{kgDM} / \mathrm{ha}\end{array}$ & $\begin{array}{l}\text { Green } \\
\text { Herbage, } \\
\%\end{array}$ & $\begin{array}{l}\text { Dead Herbage, } \\
\%\end{array}$ \\
\hline Rotational & 1034.19 & 2150.25 & 68.40 & 31.60 \\
Continuous & 911.41 & 1805.48 & 61.56 & 38.44 \\
SEM & 104.4 & 218.3 & 3.3 & 3.3 \\
Probability & $\mathrm{NS}^{\mathrm{c}}$ & $\mathrm{NS}$ & $\mathrm{NS}$ & $\mathrm{NS}$ \\
\hline
\end{tabular}

$\overline{\mathrm{a}}=$ Green Herbage percentage $;{ }^{\mathrm{b}}=$ Dead material percentage $;{ }^{\mathrm{c}} \mathrm{NS}=$ non significance 
Table 6: Effect of System, Year, and Cycle on Forage Quality (1994-1996)

\begin{tabular}{|c|c|c|c|}
\hline Item & $\begin{array}{l}\text { Neutral Detergent } \\
\text { Fiber }{ }^{\mathrm{a}}, \\
\% \text { of DM }\end{array}$ & $\begin{array}{l}\text { Acid Detergent } \\
\text { Fiber, } \\
\% \text { of DM }\end{array}$ & $\begin{array}{l}\text { Crude Protein, } \\
\% \text { of DM }\end{array}$ \\
\hline $\begin{array}{l}\text { Rotational, } \\
\text { Weeks 1-4 }\end{array}$ & 60.96 & 33.93 & 12.73 \\
\hline $\begin{array}{l}\text { Continuous, } \\
\text { Weeks 1-4 }\end{array}$ & 62.74 & 33.53 & 12.86 \\
\hline SEM & 0.8 & 0.3 & 0.3 \\
\hline Probability & NS & $\mathrm{NS}^{\mathrm{b}}$ & NS \\
\hline 1994, Weeks 1-4 & 64.05 & 34.28 & 12.08 \\
\hline 1995, Weeks 1-4 & 58.36 & 32.80 & 13.93 \\
\hline 1996, Weeks 1-4 & 62.06 & 34.02 & 12.56 \\
\hline SEM & 0.6 & 0.3 & 0.3 \\
\hline Probability & NS & NS & NS \\
\hline \multicolumn{4}{|l|}{1995} \\
\hline $\begin{array}{l}\text { Rotational, } \\
\text { Weeks 1-4 }\end{array}$ & 61.0 & 33.9 & 12.7 \\
\hline $\begin{array}{l}\text { Rotational, } \\
\text { Weeks 5-8 }\end{array}$ & 61.1 & 35.1 & 15.0 \\
\hline $\begin{array}{l}\text { Continuous, } \\
\text { Weeks 1-4 }\end{array}$ & 62.7 & 33.5 & 12.9 \\
\hline $\begin{array}{l}\text { Continuous, } \\
\text { Weeks 5-8 }\end{array}$ & 58.0 & 33.0 & 14.7 \\
\hline $\begin{array}{l}\text { Rotational,Mean } \\
\text { (Weeks 1-8) }\end{array}$ & 60.75 & 34.39 & 13.83 \\
\hline $\begin{array}{l}\text { Continuous,Mean } \\
\text { (Weeks 1-8) }\end{array}$ & 60.84 & 33.34 & 13.59 \\
\hline SEM & 0.6 & 0.3 & 0.3 \\
\hline Probability & NS & $(0.036)$ & NS \\
\hline Weeks 1-4 Mean & 58.36 & 32.80 & 13.93 \\
\hline Weeks 5-8 Mean & 59.57 & 34.08 & 14.85 \\
\hline SEM & 0.5 & 0.3 & 0.2 \\
\hline Probability & $(0.088)$ & NS & $(0.088)$ \\
\hline
\end{tabular}


Table 7: Effect of System and Year on Cow Performance

\begin{tabular}{|c|c|c|c|c|c|c|c|c|}
\hline \multirow[t]{2}{*}{ Item } & \multicolumn{4}{|c|}{ Weight at Buffer (Period 1), kg } & \multicolumn{4}{|c|}{$\begin{array}{l}\text { Weight at Weaning (Periods 1-3), } \\
\mathrm{kg}\end{array}$} \\
\hline & $\begin{array}{l}\text { Initial } \\
\text { Wt. }\end{array}$ & $\begin{array}{l}\text { Final } \\
\text { Wt. }\end{array}$ & $\begin{array}{l}\text { Total } \\
\text { Wt. } \\
\text { Gain }\end{array}$ & $\begin{array}{l}\text { Avg. } \\
\text { Daily } \\
\text { Gain }\end{array}$ & $\begin{array}{l}\text { Initial } \\
\text { Wt. }\end{array}$ & $\begin{array}{l}\text { Final } \\
\text { Wt. }\end{array}$ & $\begin{array}{l}\text { Total } \\
\text { Wt. } \\
\text { Gain }\end{array}$ & $\begin{array}{l}\text { Avg. } \\
\text { Daily } \\
\text { Gain }\end{array}$ \\
\hline \multicolumn{9}{|l|}{ Gain/head } \\
\hline $\begin{array}{l}\text { Rotational } \\
\text { Continuous } \\
\text { SEM } \\
\text { Probability }\end{array}$ & $\begin{array}{l}501 \\
519\end{array}$ & $\begin{array}{l}522 \\
540\end{array}$ & $\begin{array}{l}21 \\
21 \\
7.0 \\
\text { NS }^{\mathrm{a}}\end{array}$ & $\begin{array}{l}0.28 \\
0.28\end{array}$ & $\begin{array}{l}501 \\
519\end{array}$ & $\begin{array}{l}519 \\
543\end{array}$ & $\begin{array}{l}18 \\
24 \\
9.2 \\
\text { NS }\end{array}$ & $\begin{array}{l}0.12 \\
0.16\end{array}$ \\
\hline $\begin{array}{l}1994 \\
1995 \\
1996 \\
\text { SEM } \\
\text { Probability }\end{array}$ & $\begin{array}{l}444 \\
528 \\
535\end{array}$ & $\begin{array}{l}472 \\
555 \\
543\end{array}$ & $\begin{array}{l}28 \\
26 \\
8 \\
6.9 \\
\text { NS }\end{array}$ & $\begin{array}{l}0.36 \\
0.35 \\
0.11\end{array}$ & $\begin{array}{l}444 \\
528 \\
535\end{array}$ & $\begin{array}{l}484 \\
549 \\
538\end{array}$ & $\begin{array}{l}40 \\
21 \\
3 \\
7.6 \\
(0.021)\end{array}$ & $\begin{array}{l}0.26 \\
0.14 \\
0.02\end{array}$ \\
\hline \multicolumn{9}{|l|}{$\begin{array}{l}\text { Gain/ } \\
\text { system }\end{array}$} \\
\hline $\begin{array}{l}\text { Rotational } \\
\text { Continuous } \\
\text { SEM } \\
\text { Probability }\end{array}$ & $\begin{array}{l}24028 \\
21814\end{array}$ & $\begin{array}{l}25051 \\
22688\end{array}$ & $\begin{array}{l}1023 \\
874 \\
313 \\
\text { NS }\end{array}$ & $\begin{array}{l}13.6 \\
11.6\end{array}$ & $\begin{array}{l}24028 \\
21814\end{array}$ & $\begin{array}{l}24932 \\
22802\end{array}$ & $\begin{array}{l}904 \\
988 \\
412.2 \\
\mathrm{NS}\end{array}$ & $\begin{array}{l}5.9 \\
36.9\end{array}$ \\
\hline \multicolumn{9}{|l|}{ Gain/year } \\
\hline $\begin{array}{l}1994 \\
1995 \\
1996 \\
\text { SEM } \\
\text { Probability }\end{array}$ & $\begin{array}{l}13322 \\
15852 \\
16062\end{array}$ & $\begin{array}{l}14166 \\
16650 \\
16299\end{array}$ & $\begin{array}{l}844 \\
798 \\
237 \\
206.0 \\
\text { NS }\end{array}$ & $\begin{array}{l}10.8 \\
10.6 \\
3.3\end{array}$ & $\begin{array}{l}13322 \\
15852 \\
16062\end{array}$ & $\begin{array}{l}14523 \\
16479 \\
16143\end{array}$ & $\begin{array}{l}1201 \\
627 \\
81 \\
217.6 \\
(0.013)\end{array}$ & $\begin{array}{l}7.9 \\
4.1 \\
0.6\end{array}$ \\
\hline
\end{tabular}

${ }^{\mathrm{a}} \mathrm{NS}=$ non significance 
Table 8: Effect of System and Year on Calf Performance

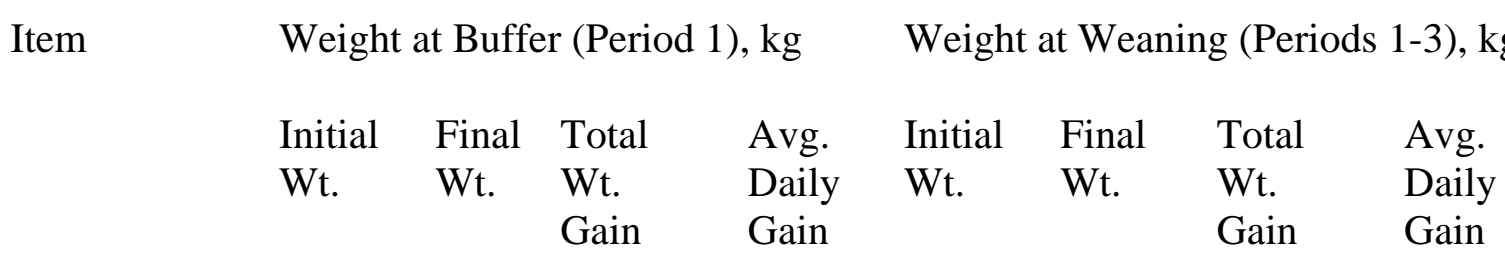

Gain/head

$\begin{array}{lllllllll}\text { Rotational } & 79 & 154 & 75 & 1.0 & 79 & 212 & 132 & 0.87 \\ \text { Continuous } & 82 & 153 & 71 & 0.95 & 82 & 215 & 133 & 0.88 \\ \text { SEM } & & & 2.4 & & & & 3.5 & \\ \text { Probability } & & & \mathrm{NS}^{\mathrm{a}} & & & & \mathrm{NS} & \\ & & & & & & & & \\ 1994 & 77 & 150 & 73 & 0.94 & 77 & 215 & 138 & 0.91 \\ 1995 & 83 & 160 & 77 & 1.03 & 83 & 212 & 129 & 0.94 \\ 1996 & 82 & 151 & 69 & 0.96 & 82 & 215 & 133 & 0.93 \\ \text { SEM } & & & 2.7 & & & & 3.9 & \\ \text { Probability } & & & (0.053) & & & & \text { NS } & \end{array}$

Gain/system

$\begin{array}{lllllllll}\text { Rotational } & 3808 & 7399 & 3591 & 47.9 & 3808 & 10188 & 6380 & 42.0 \\ \text { Continuous } & 3439 & 6330 & 2991 & 39.9 & 3439 & 9046 & 5607 & 36.9 \\ \text { SEM } & & & 108.0 & & & & 157.2 & \\ \text { Probability } & & & (0.001) & & & & (0.001) & \end{array}$

\section{Gain/year}

$\begin{array}{lllllllll}1994 & 2306 & 4497 & 2191 & 28.1 & 2306 & 6441 & 4135 & 27.2 \\ 1995 & 2484 & 4812 & 2328 & 31.0 & 2484 & 6348 & 3864 & 25.1 \\ 1996 & 2465 & 4521 & 2056 & 28.6 & 2465 & 6459 & 3994 & 27.9 \\ \text { SEM } & & & 133.6 & & & & 183.6 & \\ \text { Probability } & & & (0.046) & & & & (0.094) & \end{array}$

${ }^{\mathrm{a}} \mathrm{NS}=$ non significance 
Figure 1: 1994 Weekly Pasture Heights (Grazing Only Area)




Figure 2: 1995 Weekly Pasture Heights (Grazing Only Area)

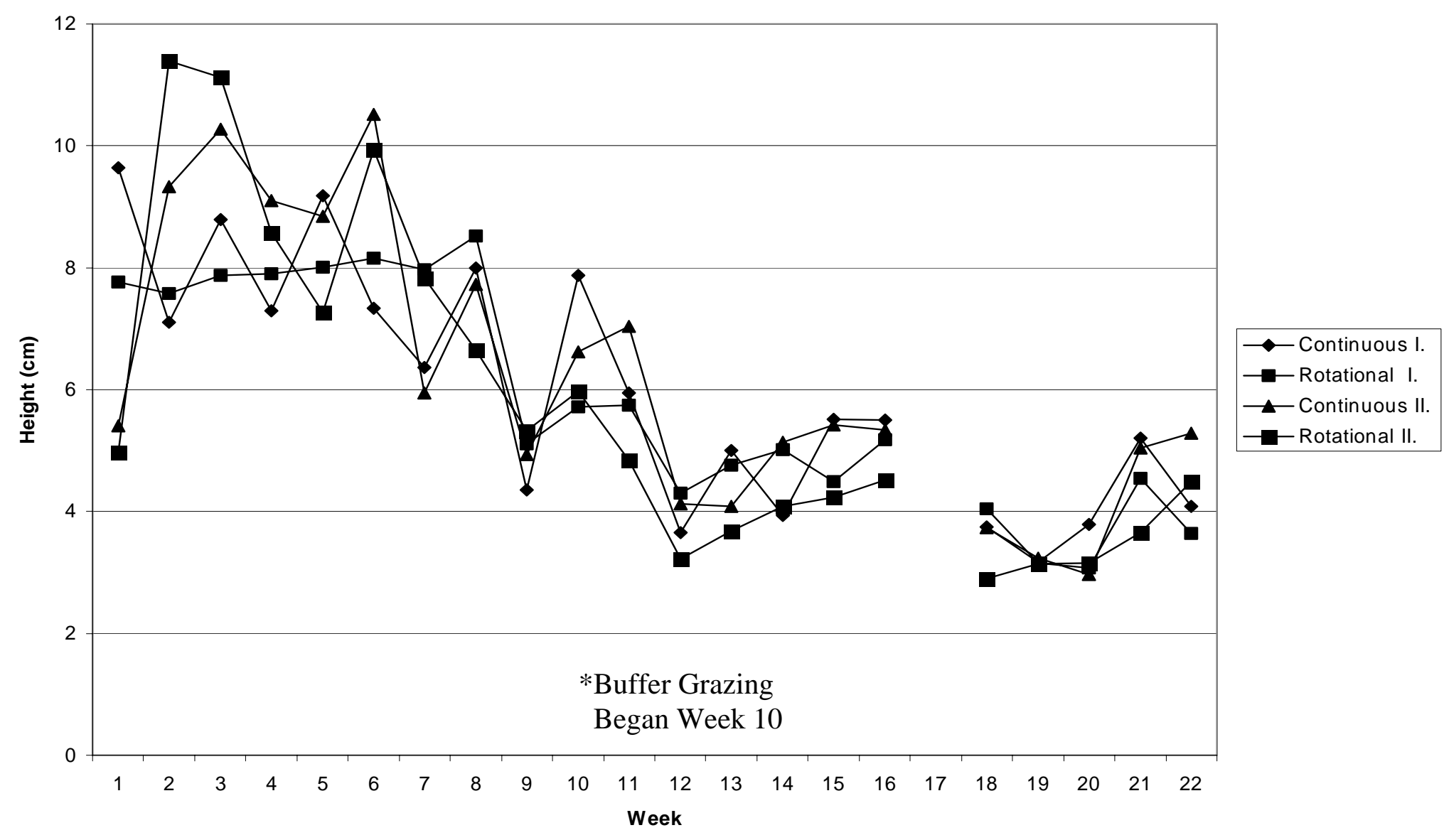


Figure 3: 1996 Weekly Pasture Heights (Grazing Only Area)

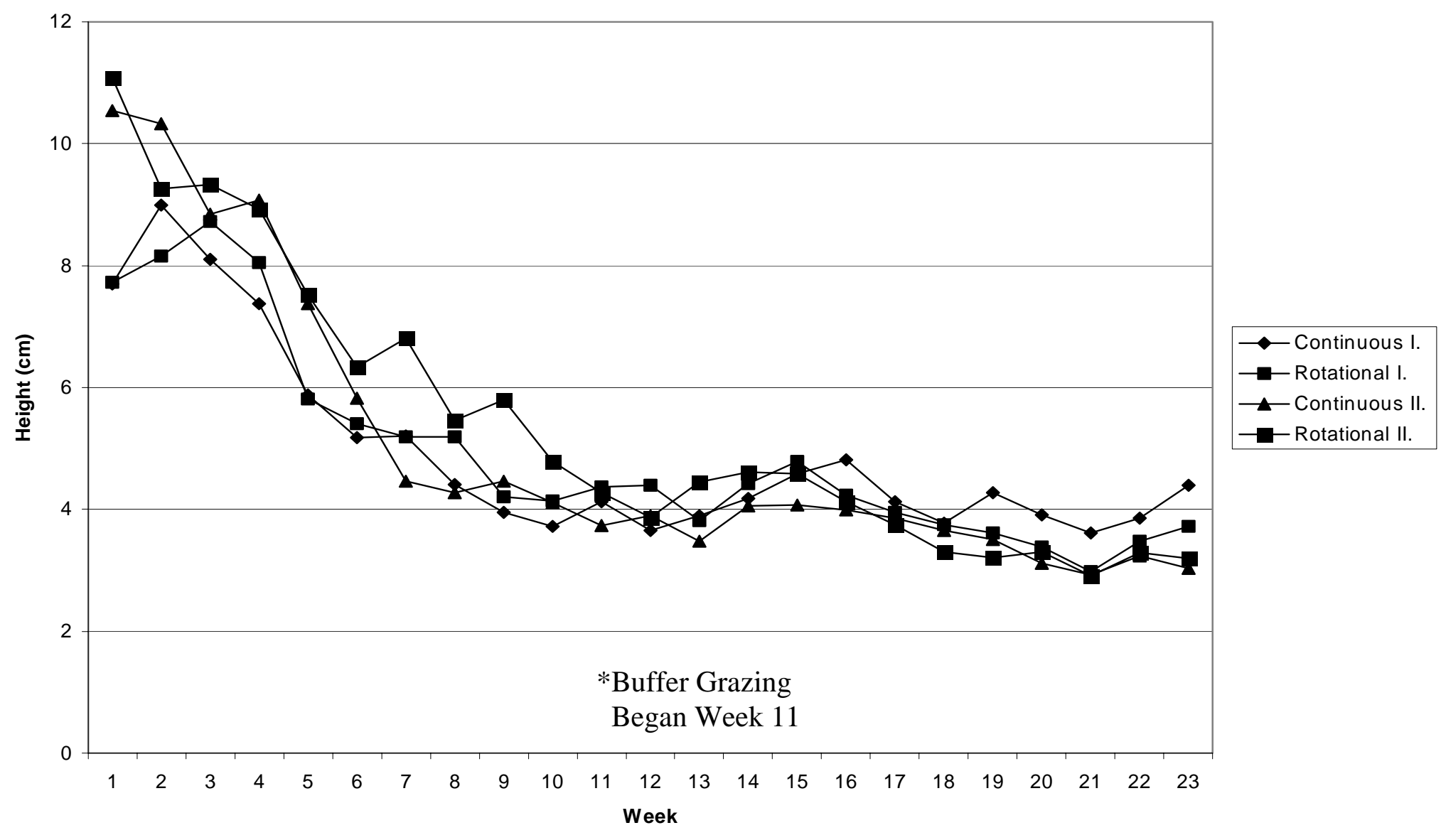


Figure 4: 1995 Pasture Growth and Precipitation

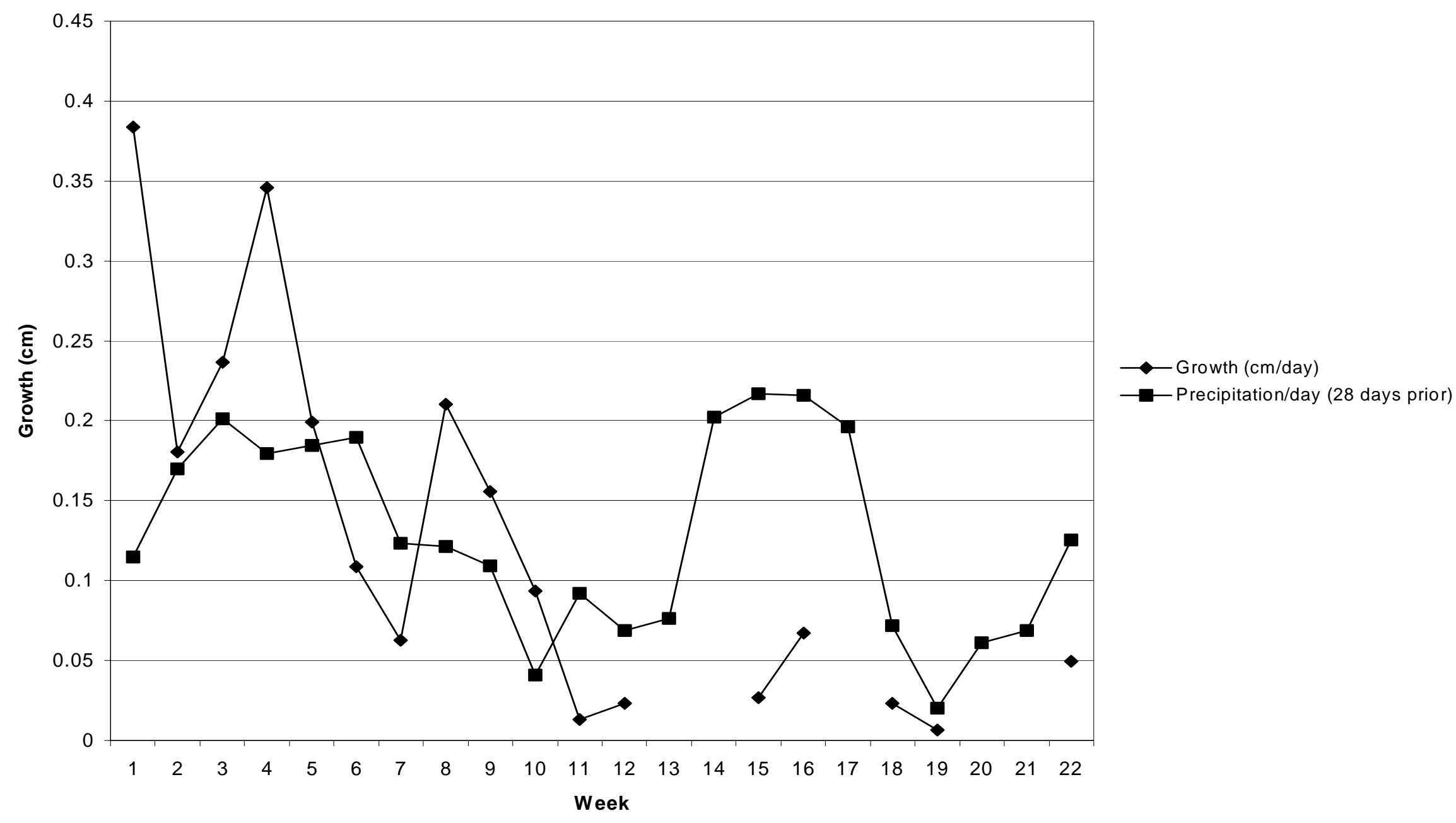


Figure 5: 1996 Pasture Growth and Precipitation

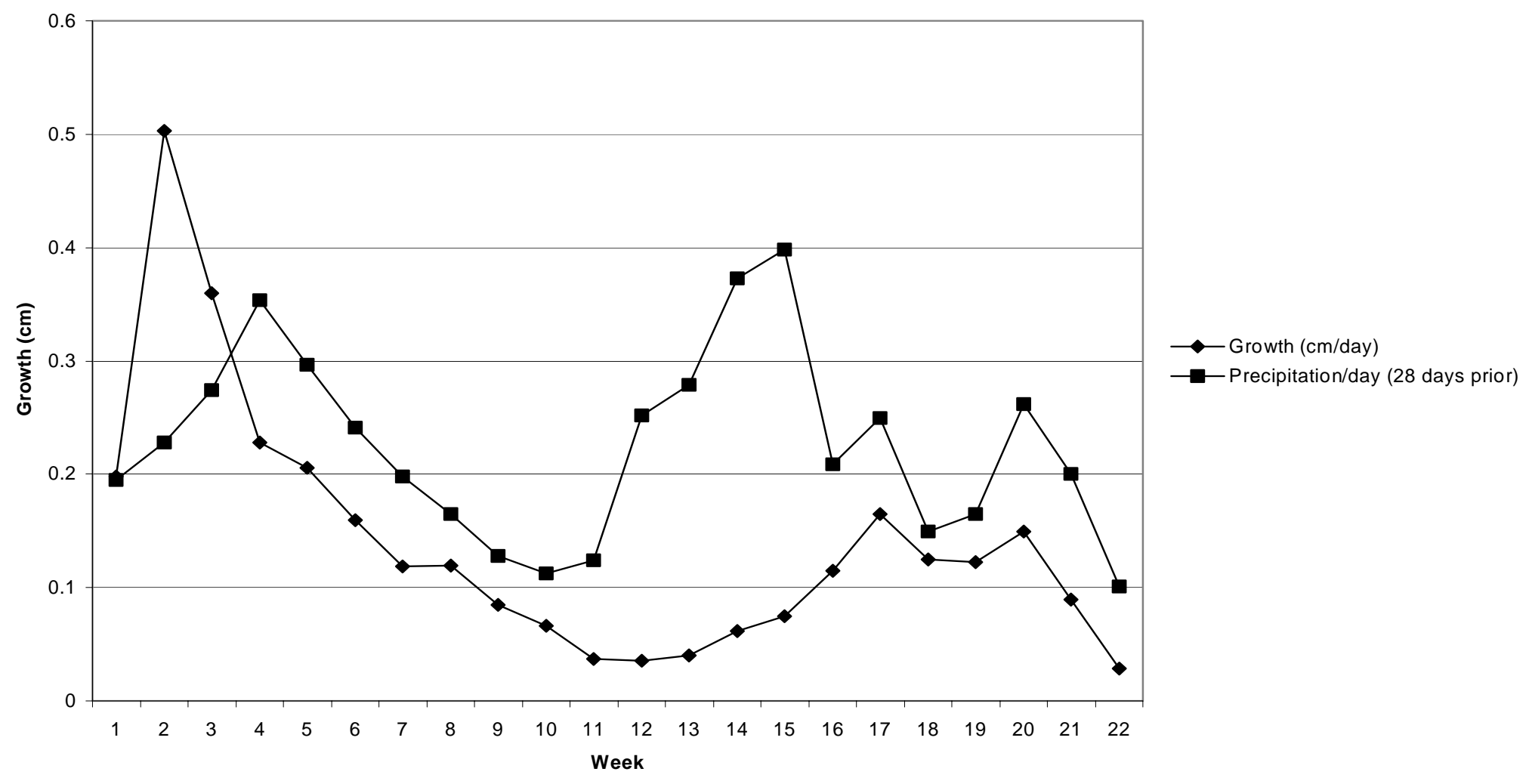




\section{VITA}

Name: $\quad$ Charles R. Wolfe III

Date of Birth: $\quad$ November 17, 1976

Parents: $\quad$ Charles R. Wolfe Jr.

Elva Lucille Wolfe

Family: Rachel Sue Wolfe, Sister

David Wolfe, Brother

Institutions Attended: $\quad$ Brownsville Area School District

$1982-1995$

Penn State University

$1995-1999$

West Virginia University

$1999-2001$

Degrees Awarded: $\quad$ B.S. Animal Bioscience,

Penn State University

1999 